\title{
ELECTRON MICROSCOPIC OBSERVATION ON THE SEROUS CELLS OF THE HUMAN NASAL GLANDS.
}

By

\section{T. TAKAHASHI}

\section{From the Department of Otorhinolaryngology School of Medicine Keio University.}

(Director: Prof. T. Nishihata)

The author investigated electron microscopically the fine structures of the serous cells of the human nasal glands. The results obtaind were as follows.

(1) The cells changes morphologically compexly and subtly corresponding to the stage of their secretory function.

When the secretory granules start to appear, the nucleus is situated nearly at the center of the cell and shaped round.

The infranuclear zone is abundant in lamellar endoplasmic reticulum (E R.), and in the supranuclear zone well developed Golgi bodies are recognized.

Morphologically typical mitochondria are distributed evenly in the whole field of the cell, with the apparance and increase of the secretory granules, the nucleus is gradually lowered downwards and transformed, and the E.R. and Golgi bodies lose their lammellar structures and get obscure.

In the loaded phase, the mitochondria show a tendency to expand diminish.

Just after discharge of the secretory granules, R.N.A. granules are scanty, the E.R. is swollen and gets vacuolar, and the mitochondria are scarce and remarkably expanded

In the next stage, the vacuolar E.R. aggregates densely, the cell looks apparently reticulated, and the mitochondria start to increase.

Furthermore, the R.N.A. granules increase and compressed E.R. shows an imcompletely lamellar structure. Thus the cells is in the presecretory stage.

(2) In the early stage the secretory granules are formed in the Golgi apparatus and seem to arise from any of Golgi granules, Golgi membrane and E.R. in the Golgi apparatus. Extending over the preparatory and the loaded phase, they are seemingly formed chiefly in the supranuclear zonea nd arise from the degenerated mitochondria with R.N.A. granules on the circumferences.

(3) The so called "lipochonria" of Baker are encounterd. Lipoid granules and lipochondria are recognized in all the stage of the secretory cycle, and even in the myoepithlial cells.

(4) Transitional picture between the exomembrane of the nucleus membrance and the E.R. was seen.

(5) Between the adjoning cells were recogneized the "desmosome" and "terminal bar" which had not been proved by light microscope.

They were very similar to each other, but author realized that there were some differences between them.

(6) There are microville on the free surface of the cell facing to the lumen.

They seem to change corresronding to the secretory function of the cell.

(7) Intercellular secretory canaliculi are often found, the lumen of whieh is rich in microvilli.

(8) Remarkable intercellular interdigitation are recognized at the boundary between the adjoining cells and infoldings are seen in the basal part of the cell.

The basal infoldings are not so remarkable as those of striated cells of the salivary glands or epithelial cells of the kidney. 


\section{人鼻腺漿液細胞の電子顕微鏡的観察}

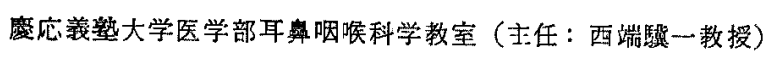

助手 高橋 徳 三方郎

\begin{tabular}{|c|c|}
\hline & 次 \\
\hline 第 I 章 & 粕 \\
\hline 第】章 & 研究材料及び方法 \\
\hline 第 II章 & 自家所見 \\
\hline 第 1 慨 & 角舅腺獎液細胞の棈造 \\
\hline (A) & 分泌遇期に応ずる細胞の一般的変化 \\
\hline 1) & 分泌顆粒出現の極初期の細胞像 \\
\hline 2) & ）分泌顆粒出現時の細胞像 \\
\hline 4) & 分泌顆粒充盈期の細胞像 \\
\hline 5) & ）分泌顆粒空虚期の細胞像 \\
\hline 6) & ）分泌休止期の胞細像 \\
\hline
\end{tabular}

〔B〕液細胞の細胞形質

1) 糸粒体

2) Golgi 体

3) 小 胞 体

4) 分速顆粒

5) Lipoid 顆粒及び lipochondria

〔C〕 細 胞 膜

1) Microvilli

2) 細胞間炭合と基底陷入

3）細胞間分泌稩管

4）閉鎖堤及び desmosome

(D) 核
1) 核 質
2) 核 小 体
3) 核 膜

第】節 分泌顆粒の形成機序

(A) Golgi 野に出現する分泌顆粒

〔B]系粒体より転化する分泌顆粒

第 $\mathbb{V}$ 章 総括及び考按

1）分泌週期に応ずる細胞の変化

2）分泌顆粒の形成譏序について

3) Lipoid 顆粒及び lipochondria 第 $V$ 章 結 語

\section{第 1 章 緒 奉}

副鼻腔を含めて乎吸部鼻粘膜に分布する人の鼻腺

Glandulae nasals. Nasendrüse. nasal glands 混合
腺であることを最初に主張したのは Stöhr (1886) で， 今日では一般にその搆造は管状胞状分枝混合単，一腺， tubülo-alveoläre verzweigte gemischte Einzeldrüse. として認められている (Denker-Kahler 1925, Bargmann 1956. etc).

しかしその微細構造について研究した学者は全くない といつて過言でない。

岩井 (1958) は光学顕微鏡により人の鼻腺々細胞の夈 粒体及び Golgi 装置を中心としての分泌像を詳紐に䂓 察し，その形態から分泌機序を解明した最初の研究者で ある・

彼によれば人の鼻腺には純粘液腺も, 純漿液腺す存在 せず，その分泌部はすべて一定の法則に基いて分布する 粘液細胞と夜細胞とからなる混合腺で，これら両種腺 細胞は各々独立した分泌像を示し，決して互に移行する ことはない。

粘液細胞に叔ける粘液顆粒はへマトキシリン, エオジ ン染色，Heidenhain 氏鉄认マトキシリン染色，Kull 氏 染色等により染まらないので空胞状に見える.粘液顆粒. は先づ初めに Golgi 野内で形成され，次いで細胞先端 部に移動してそこに集䅡する．粘液顆粒が增量すると細 胞は肥大し，核は強く細胞基底部に压迫され，変形し， 濃縮に脂るようになる・か」る粘液顆粒の形成は Giolgi 装置が主として関与し，糸粒体は関与しない。

これに反し漿液細胞においては㹊液顆粒は系粒体から 形成され，Heidenhain 氏鉄へマトキシリン染色，Kull 氏染色の Anilinfuchsin 等で強染する. 又棌液顆粒に は非染性の分泌空胞となるものもあるが，しかしこれら の分泌顆粒の増量に基いて核が粘液細胞比ける如〈強 く変形, 濃繀することがないので両種腺細胞を鑑別でき ると述べている。

しかしこのような事実についての電子顕碳鏡的研究は 今日な和全く行われていない。

そこで私は電子顕微鏡の優れた分解能を利用して人の

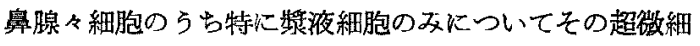
構造を明らかにし，併せてその分汹機構を解明しようと 試みた。 


\section{第 II 章 研究材料及び方法}

材料は满 6 力月から 54 才に至る男, 女9 例の下鼻介
粘膜で手術に際し粘膜に対する侵基を避ける目的で凡て 全身林醉下棌取した (表).

秦

\begin{tabular}{|c|c|c|c|c|}
\hline 番昜 & 氏 名 & 性 & 年 令 & 族 \\
\hline 1 & Y. I. & 男 & 54 才 & 喉 \\
\hline 2 & Y. O. & 男 & 5 オ & 扁 桃 肥 大 \\
\hline 3 & N. O. & 男 & 22 才 & 先天性頸部羁腫 \\
\hline 4 & H. S. & 男 & $11 才$ & 屏 桃 肥 大 \\
\hline 5 & N. K. & 女 & $15 才$ & 副 鼻 空 炎 \\
\hline 6 & Y. S. & 男 & 22 才 & 先天性喉頭狭窄 \\
\hline 7 & A. I. & 男 & 6カ月 & 口 蓋 破 裂 \\
\hline 8 & Y. W. & 女 & 48 才 & 舌 \\
\hline 9 & T. I. & 男 & 36 オ & 副 舅 腔 炎 \\
\hline
\end{tabular}

材和は下甲介剪刀を用いて約 $3 \times 3 \times 10 \mathrm{~mm}$ の归平な 紡錘形の粘膜片として採取し，直らにこれを固定液を滴 下した歯科用シートワックスの上で約 $1 \times 1 \times 2 \mathrm{~mm}$ の長 方形の小紐片に切断し子ぬ用意したペニシリン篡中に移 して氷室中で 2 時間固定を行つた。

固定液は $\mathrm{pH} 7.4$ K調整した Acetate-Veronal の緩 衝液と，2\%オスミウム酸容液を等量に混じたものを用 いた. 固定完了後 isotonic Bufferにて2〜3 回洗滥し, 35\%より 100\%に至る上昇アルコール柔列にて各々 30 分脱水し，包埋には n-butylmethacrylate と methylmethacrylate $7: 3$ の割に混合したモノマーに, 重合 促進剂として過酸化ベンゾイルを $1 \%$ の割版光，投薬 用ゲラチンカブせルK分注して䄪 $50^{\circ} \mathrm{C}$ の恒温器内にて 重合を行つた。

超薄切片の作製には自製の Latta-Hartman 型ガラス ナイフを取りつけた島津型迴転式ミクロトームを用い, 切り出された切片の中から干啮色による推定の厚さ約 $0.03 \mu$ の切片を選び，包埋郕を除去することなく日立製 $\mathrm{Hu}-10$ 型電子影微鏡を用いて観察した，写真撮影は值

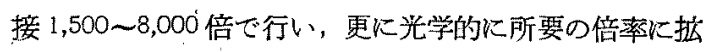
大して観察した。

な和対照として超薄切片作製に当り，荒削りで切り出 された此較的厚い切片を同時にスライドガラス上に貼布 し，これを宁セトンにて脱包理して，ギムザ染色及び PAS 染色を行い龹学顕微鏡下に比較観察した。.

\section{第III章自家所見}

第 I 節 舅腺嶈液細胞の構造

〔A〕分泌週期に応ずる細胞の一般的変化 分泌機能を有する腺細胞の微細構造はその分泌週期に

\begin{tabular}{|c|c|c|}
\hline 手 & 麻 & 採取部位 \\
\hline 喉 頭 全 摘 & 気管内麻醉 & 下泉甲介 \\
\hline 扇 桃 摘 除 & " & " \\
\hline 羁 睡 摘 出 & " & " \\
\hline 扁 桃 摘 除 & " & " \\
\hline 副鼻腔炎手術 & $"$ & " \\
\hline 喉 頭 成 形 術 & $"$ & $"$ \\
\hline 口蓋破裂成形術 & $"$ & " \\
\hline 苫 切 除 術 & $"$ & $"$ \\
\hline 副鼻腔炎手郝 & $"$ & $"$ \\
\hline
\end{tabular}

応じて甚だ複雑改妙な変化を示するのである．特に電子 顕微鏡像によりこれら腺細胞の超微細構造を解読するこ とは極めて困難であつた。 そこで私は超薄切片の一部に ギム゙サ染色及び PAS 染色を施して光学的に鏡検し，努 めてこれを対照し作ら電顕写真を観察した.

1）分泌顆粒出現の極初期の細胞像（図 2)

紐胞の外形は長円柱形である。汪ざ正円形の核は細胞 の中央位よりや〉基底面寄りに位置して，核下部には細 胞基底面との間にかなりの広さの細胞形貿を認める。 こつには後述するような層板状の粗面小胞体 rough surfaced variety of endoplasmic reticulum (以下 ER と略す）が豊富に集䆄している。この粗面小胞体の間の 細胞形質には多数の長桿状. 桿状, 円形の糸粒体を認め る。核上部には後述するような層板状に配列する滑面小 胞体 smooth surfaced variety of endoplasínic reticulum からなる Golgi 膜々 Golgi 顆粒及び Golgi 空胞 により構成された良く発達した Golgi 体が認られる。 Golgi 膜によつてほら゙馬蹄形に囲まれた内部には Golgi 顆粒上りや小大きい高電子密度の顆粒が認められる.こ の顆粒はその微小なるのが附近に在る Golgi 䫓粒に近似 する所から Golgi 顆粒の増大したるので，恐らく分泌 顆粒の前段階であろうと想像している.

しかしか〉る所見は分泌顆粒の出現極初期沈の慧め られるもので䅉々遭遇する所見ではない。従つてからる 題粒形成は極初期に的ける一つの分泌顆粒形成過程であ ろうと考える.

(図 2)の核上部左方に見られる大小 2 ヶの高電子密度 の著明な限界膜を有するかなり大きい顆粒は後述するよ らな lipoid 顆粒である。 
この時期の細胞には一見明らかに判定し得るょうな分 北顆粒は全く認められない，核と細胞腺腔面との間にも かなりの量の禾粒体を認め得るが，細胞腺腔面に近い部 分にはこれを認めない。

上記のような細胞小器官を含し細胞形貿はその基貿に RNA 顆粒，あるいは Palade の顆粒之乎ばれる微細顆 粒 microsome を汪が平等に分布するため全体として暗 調である。

腺腔に面する細胞遊離表面は平滑で，後述するような microvilli を殆ど認めない。

隊接細胞間には腺腔面において閉䥊堤 terminal bar を, 又細胞間にはかなり発達した細胞間嵌合 intercellular interdigitation を認めるが，細胞間陌 intercellular space は㱠ぞ認められない。

\section{2）分泌顆粒出現時の細胞像（図 3）}

前記細胞の近くに見られる細胞において，Golgi 野及 び核側部に数ケの分泌顆粒が出現している. 分必顆粒の

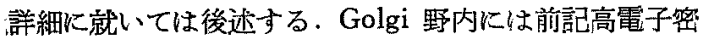
度の小顆粒 1〜2 ケとをの顆粒の的 2〜3 倍の大きさで，

円形㫧粒体よりや」大きい，電子密度の少し低い顆粒 3 ヶが出現している．核側部に見られる顆粒もは心゙同様の 構造を示している。

これらの顆粒はギムザ染色及び PAS 染色標本に沶い て光顕的に認められる分必顆校と大きさ，及び位置的に

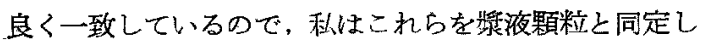
た.

又前期極初期像に扣いて，Golgi 野内に出現した高電 子密度の小顆粒は分泌顆粒の出現と共にその数の減少す る事，及びこの顆粒が分泌顆粒へ移行すると思われる像 が認められるところから私はこの顆粒が分泌顆粒化する ものと考光，これを極初期分泌顆粒と呼ら゙ことにする。 しかし後述するように分泌顆粒の産生旺感な時期におい ては常にからる形成機序を示ちものではない。

このように分必顒粒が出現すると, 正円形の核はや〉 細胞基底面に近く位置するようになり，核下部では ER の層板状構造は不明瞭之なる。しかしな和核側部及び時

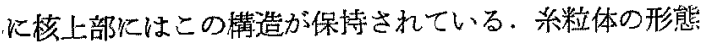
及びその数量には大した変化はない，細胞腺腔面にはそ

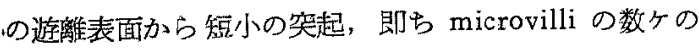
出現を見る。

3）分泌顆粒補充期の細胞像（図 4，5）

分泌顆粒主增大し，增量して核上部，Golgi 野及び細 胞腺腔面近くに集積する。その形は一般に円形で時に棉
状，紡蹅形，卵円形のるの混在する場合があるが，甚 だしい異形性を示すことは殆どない，分泌顆粒の外周に は著明な限界膜を認めず，その内部棈造は坛留性で，電 子密度檽內て高いものと, 中等度のものとあつて, 濃淡 2 種の像を認める。一維炍高電子密度の暗調顆粒 (osmiophilic granules) ( 子密度の中問調顆粒は核々の中間域烘在する。

同一超薄奵片材棜のギムザ染色標本を光影的に観察す ると, 紐胞遊離表面に近く集䅡した分泌顆粒は澧紫色に 好染し，核との中間域にあるそれらは淡染するところか ら, (図 4) の電顕像の 暗調顆粒はギムザ好染顆粒に, 又中間調顆粒はギムザ淡染㩆粒と一致する.

しかし PAS 染色標本ではからる着染珄の相違は左程 著明ではない，岩井 (1958) は漿液顆粒すPAS 反応陽 性を示寸と述べているが超薄切片の光顕像においてる同 様の所見が得られた。

この時期の核は細長の細胞では長軸に平行して位置す る棈円形のもの，あるいは円錘形細胞では横位に位置す るものを時代認めることがあるが，一般にはな扔円形で ある、しかし核表面は平滑でなく，小凹凸あるいは小波 状を呈するものが多い。

Golgi 膜はな和良く発育した層板状棈造を示し，網工 を形成している.

$\mathrm{ER}$ は一般にその層板状構造を失い，断片的に散在す 当場合加多心。

米粒体は断面で長棏状，桿状，円形のるのが細胞形質 内に汪が平等に分在しているが，細胞遊離表面近くでは 殆ど認められない，microvilli は前記時期よりや〉増量 している.

4）分泌顆粒充盈期の細胞像（四 6)

細胞全面に分泌顆粒が充盈すると, 細胞は膨大して核 は細胞基底面に接して位置するようになる。しかし核は 強く変形したり，濃縮傾向を示すことはない。

この時期の分泌顆粒は著しく增大して中等電子密度の 中間調顆粒が多くなるが，な技先の間に少量の小さな高 電子密度の顆粒が混在している，個々の分泌顆粒は従つ て大小整タであるが，その形は活ら゙正円形で互いに触合 するようなことはない。

これらの分泌顆粒に麻々之の何部に円形，楕円形の無 構造な空胞を認めるものがある：通常人なる中間謵顆粒 と特いてその傾向が著しい。この点に就いては後述す る.

分泌顆粒の間には桿状，円形の，時には著しく膨化し 
た糸粒体を認めるがその量は減少している．Golgi 体， ER は不明膫であるが，私の材料では充盈期のるのが少 く，又その電䫓像の良好なるのが少いので多くを述べる ことができない。

細胞間厥合，細胞間隐は殆上消失して潾接細胞は泌に 接菅するようになる。

細胞遊離表面に和ける microvilli はこの時期の 細胞 では減少の傾向を示する，全く消失することはない。

5）分泌顆粒空虚期の細胞像 (図 7，8)

洯液珄分汹顆粒が腺腔内に排出されつ〉ある時期の電 顆像に私は遭遇しなからたので，その排出様式沈就いて はこつに述べることができない。

しかし細胞内に分泌顆粒を殆ど，あるいは全く，認め ず，且つ糸粒体及び ER に異常の变化を示す細胞をる つて私は分泌顆粒排出後の細胞と考えた。

(1) 排出直後と思われた細胞 (図 7)

細胞内に分泌顆粒を認めず，細胞形筫には palade の 顆粒に乏しい，著しく淡明な細胞に遭遇する．かつる稩 胞の核の外周は凹凸不平で波状を呈し，系粒体は比較的 少量で著しく膨化して抢りその大なるものは典型的絃 体の 3 4 倍に達するものもある。糸粒体の matrix は 附近細胞形質基貿の電子密度より更に低く淡明で，その 内部穼 cristae mitochondriales 恃著しく不規則な形態 を示す，一般に短小で，時に欠如している如きものがあ る.

ER は胞状でその数は少く細胞内に散在性に認められ

る. 䉼面で短管状を呈する簡単な層板状の ER は移に しか認如らない。

これらの細胞はいずれも細胞外周附近が特に低電子贸 度である，即ち，細胞膜に近い細胞形質中に淡明な層の 存在を認める.

(2) 排出後や小時間を経過したと思われる細胞(図8) 胞状に膨化した ER は增量し，密策性となり互いに 相隣接して細胞内の小胞腔が占める割合は極わて大とな り，細胞形貿基質はとれらの間に在つて網の目のような 外観を呈している。 この細胞基留には palade 顆粒がや や堌量して暗調に見え，こ」に典型的形態を示可条粒体 か゚かなり豊富に認められるようになり，細胞周辺部の淡 明層は消失している。

か人る細胞像は充盈期の細胞から分泌顆粒を取り除い 大所見と考えてみることができる. 即ら ER の胞状化 は分泌顆粒の占有していた部分方分泌顆粒排出後に空虚 となりその余地を補充するように ER の膨化してでき
たものと考える。

6) 分泌休止期の細胞像（図9)

細胞形貿内に分汹顆粒が認められず，且つ胞状 ER の認められない時期の細胞を私は分泌休止期の細胞之考 えた。

この時期の細胞には糸粒体は長桿状のものが多く, 又 細胞形貿の電子密度子低く，比較的淡明に見られる。 ER は短い二重膜構造として断片状に細胞全面に分右し ている．時に核周国において不完全乍ら層板状楧造を示 すものがある．核はなお 細胞基底部㟢りに在つて正円 形，棈円形のもの>酒かその表面の凹凸不平で波状を呈 するものがある。

かつる分泌休止期の細胞は空虚期の細胞の細胞基筫に palade の顆粒，その他の成分が 再生增量した〉ぬに胞 状の ER は压迫せられて互い滵倿し，曾板状構造

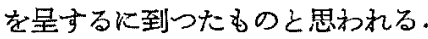

以上の所見により私は先ず分汹顆粒の排出に当つて絉 粒体の滅少と共に細胞基質が低電子密度で淡明であるの は palade の顆粒の沈盖した糸粒体が分泌顆粒化して排 出される、ためと解秎した。

分汹顆粒を排出し，ER の胞状化した細胞は前述の如 く休止期の細胞を経て細胞基貿に palade の顆粒，类粒

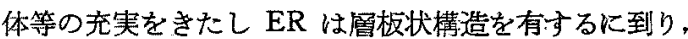
Golgi 体も亦典形的な，馬蹄形の 層此状構造 となつてそ の内部に再び初期分这顆粒の形成を見るようになりこ こに分泌週期の一巡を終るものと考える。

〔B] 称液細胞の細胞形啠

1) 系粒体 (図 8,9)

一般に釆粒体は円形，卵円形で，㳟々これらにまじつ。 て長楕円形長桿状のものを認める。元れらの横径はほ心 一様である. 粒体膜 mitochondrial membrane は二 重膜よりなり，米粒体基筫 mitochondrial matrix に比 してや〉電子密度大である，米粒体の内部には米粒体内: 部梁 cristae mitochondriales (又は internal ridges). が認められ，二重膜構造を有する。

系粒体队部梁は糸粒体獏から発して対側に向い，糸粒 体長軸に対してほ心゙直角に並列する縞状構造を示す興型 的な形のものが最る多いが，時にはその走行不規則なも の，弧状のもの，あるいは一側から他側に架橋している 如くに見えるものがある。

内部梁の基筫は特に電子密度大で，愿々その二重膜構 造の不明瞭な場合があり，単なる濃厚な線として認めら れることがあるが，その特有な構造から他の細胞小器官 
と鑑別することは容易である。

以上のような所見は palade(1953), Sjöstrand(1953), Sjöstrand と Rhodin (1953), Sjöstrand と Hanzon (1954a）等により記戴された糸粒体の基本構造の所見と 良く一致なる。

か」る糸粒体は分泌顆粒を全く持たない休止期から分 泌顆粒の出現した補充期までの各期細胞に認められ，細 胞の腺腔面に近い部分を除き，主として核を中心として 細胞全面に均等に分布する。

分泌顆粒の著しく出現している部位で糸粒体が減少す るような場合がある（図6）。この所見は岩井 (1958)の 人鼻腺，及び北村 (1958) の豚の汗腺において認めた所 見と似ている。

更に分泌顆粒が細胞全面に出現して，将に排出されん とする時期においては糸粒体は核上部において甚だしく 减少している，分泌顆粒の排出されたと思われる時期の 空虚の細胞においては膨化した糸粒体が認められる（図 7).

このよらな糸粒体は上記典型的なるのに比しその横堡 に柇いて2〜3倍大に膨化し，正円形，留円形となり， 時には腫瘤状のあのも見られるが長桿状のものは諗めら れない.

その基質は細胞基質に比し低䉓子密度で莣だしく淡明 に見える. 㕛絃体の内部梁は著しく短くなり，不規則 で嬮々減少して，㭙に全く消失しているわのあある。

Gansler 及ぴ Rouiller (1959) 等によれば䋛体の 変化には膨化と蓄穦とがあつて，前者は糸粒体内に水分 が浸潤するために起るすのと解され，従つて糸粒体は容 積を增し球状となり内容は明謂化してくる，又内部梁は 隇少し糸粒体膜の内側に貼りついたようになつてくると 云う。私の榃わた糸粒体の膨化はこの所見及び坂口と鈴 木（1959）の認めた馬杉䡰炎家雭の近位尿細管主部の所 見に良く一致している。

従つて私は將液細胞の充盈期に拈いてかなり多量の水 分が含有されているるのと思惟する。

しかし糸粒体の変化が更に高度となり, 数個の糸粒体 が融合したり，病的変化と思われる空胞状の変化を示す

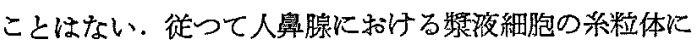
見られる膨化現象は病的变性ではなく，漿液細胞の分泌 機能に対応する. 即ち分泌週期に応じて变化する糸粒体 の生理的变化であるらと考光られる。即ち体止期におい ては長稈状の比較的長軸の長い糸粒体が多量に認められ るが, 分汹顆粒の出現と共にこれらの糸粒体は減少し,
円形，卵円形のるのが堌加し，分泌顆粒が細胞全面に充 盈する時期になると，糸粒体は膨化しとの数を減ずる。 分汹物質を排出して空虚となつた細胞に沶いては胞状 ER の間にこのよ5な糸粒体をかなり認める。

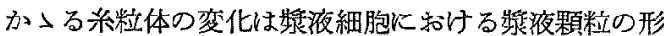
成排出の過程に扣いて水分の代謝に密接な関原がある。 の之思如机。

2) Golgi 体 (図 5, 10)

人の奥腺々細胞に和いて Golgi 淩置を証明した研究 者は恐らく岩井 (1958) が最初であらう．Golgi 装置は 光影的に岩井が認めた如く，私のギムザ染色䅺本です核 上部に蛙いて，核に接して明調な鹄曲する網工状細管， 即ち Golgi 装置の陰像として認められる.

篂顕的に観察すると，この部分は学曲した数尿に並ふ 層板状の Golgi 膜之, この周囲に暗調な Golgi 顆粒之 を認め得るが, Golgi 空胞は左程著明ではない。この構 造は光顕的に 認められた Golgi 装置に二致する電顕的 Golgi 体の構造である。この部分を更に高倍率で観察す ると並行に走る 2 本の線が一対となつてこれらが数尿に 集合して配列している。これは一対の小胞膜からなる小 胞体により構成されたすので，小胞膜の表面に細顆粒の 附着を認めないところから滑面小胞体 smooth surfaced variety of endoplasmic reticulum から成ることが判 明する.この滑面小胞体の層板状配列は人の鼻腺槳液細 胞に和いてはかなり明膫に馬蹄形を呈して認めることが できる. か」る Golgi 体は光顕的に Hirschler (1927) の云う複合型 Komplexe Form K属するるのである.

紐胞の分汹機能が旺盛となり，分汹顆粒の産生が始ま

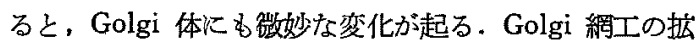
大, あるいは，Golgi 膜の細胞周过部への 生排等であ る。

3) 小胞体 (図 2,3，7，8)

Palade と Porter (1952), Palade (1955), 渡辺(5195) 等により詳細に研究された endoplasmic reticulum を

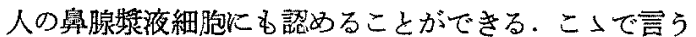
ER 即ち小胞体は小胞膜の表面に細顆粒が一曆に密に附 着した rongh surfaced variety of endoplasmc reticulum 即ち渡辺の云ら粗面小細体を指すことにする。

ER はしかし人の鼾腺の嶈液細胞においては常厄同し 形態で分布するものではない、分泌顆粒出現の極初期の 細胞においては著明な尿板状を呈し，豊富に主として核 下部に見られる。この揚合 2 線に並ぶ小胞膜の表面には 電子密度の高い細顆粒, 即万 RNA 顆粒又は Palade の 
顆粒と呼ばれる細顆粒が密着し，小胞膜に狭まれた内部 即ち小胞腔は一般に周囲細胞基貿より高電子密度で暗調 を呈し，無構造である.

核上部より細胞先端部にかけては ER は通常核下部 に执ける程著明な層板状配列を示すことなく断片状に散 在している。

分泌顆粒が出現して, 次第にとの量を增すと, この層 板状構造の ER はそしくなり断片的に散在するように なる.断片状の ER は断面ては短管状を呈しその基本 構造を失うことなく分必顆粒の間にる認められ，ほ心゙細 胞全面に散在している.

分泌顆粒を排出した直後と思われる空虚期の細胞にお いては不規則な形態を示す ER が出現する. 即ち小胞 腔は拡大, 膨脹して空胞状を示し, その内部は空虚に見 えて極めて明調である。

分泌顆粒を排出しゃ〉時間の経過したと思丸れる細胞 に持いてはか子る胞状の ER が細胞の大部分を占め, 細胞基質はそれらの間に压迫せられてあたか子網の目の 如き外観を呈している.

4) 分泌顆粒

分泌顆粒の出現した將液細胞を電顕的に観察すると， その補充期の初期においては, 細胞腺腔面に集䅡した顆 粒は高電子密度の暗調顆粒として認められ，核との中間 域には細胞基質よりや〉高い電子密度を有する中間調顆

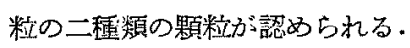

この切片の一部をギムサ染色で光顕的に観察すると， 細胞腺腔面近くに批りる顆粒は濃紫色に着染し，核との 中間域では淡染性に着染しているが，この所見は電顥像 の暗調顆粒と，中間調顆粒にそれ炎れの大きさ，出現部 位等加ら一致する.

又 PAS 染色䅺本においてはこれらの顆粒はいずれる PAS 陽性反応を示すが，着染性に濃淡の差を示すこと はない，岩井 (1958) も光顕的に同様の所見を忍めてい

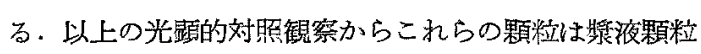
であろうと考えられる.

Bronnetta, L. S. and Daniel, D. P (1959) は rat $の$ 耳下腺々房の漿液細胞に抽いて，2 型の分泌顆粒を認 め，第 I 型は明瞙な限界膜に包まれて坛質性低電子密度 の基貿を有し，この基䓄中には此較的密度の大きい細毛 (flocculent)を認めるひの，第型はかなりの電子密度 で密な微細顆粒の集合からなると云い，I型から型へ の移行型をる認め得るところから、これらは分珌顆粒の 成熟過程を示しているものと想像している。しかし私の
標本では分泌顆粒は一般に著明な限界膜を認めないここ の点は彼等の所見と異るところである. 又彼等は第『型 の顆粒は補充期に出現し, 細胞先端部に現局して中等量 にしか認められないといらがこの所見は私の暗調顆粒 の所見と良く一致する.

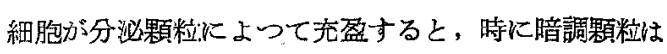
甚だしく減少するか，あるい性全く消失するが，この所 見剪期 Bronnetta, L. S and Daniel, C. P.の第 I 型 は時に充盈期に見られ，細胞全面に出現するといら所見 に良く一致する。

5) Lipoid 顆粒及び lipochondria（図 2, 4, 12)

人の鼻腺々細胞に屡々,かなり大きな円形,卵円形の明 瞭な限界膜を有する顆粒を認める.その基質の電子密度 は暗詞分泌影粒と中間調分泌顆粒との中間程度で, 時に その内部に 1〜数ケの空胞を認めるものがある(図 1,2) この顆粒は多い時は一つの 細胞に 4〜5個を数光，主と して核上部に認められるが，時には核側部，下部にも認 あられる。

この切片の一部をギムザ染色, PAS 染色し夫々光顕 的に観察すると。いずれの染色にも着染すず，光を強く 屈折する光骦性のや〉淡黄色を帯びた顆粒として認めら れる. 又人鼻腺々細胞に出現する岩井 (1958) の認めた lipoid 顆粒極めて良く類似しているところからこの 顆粒は脂質を含も顆粒であることには間違いない．

しかし光顕的に汗腺等に見られる脂肪滴の如くオスミ ウム酸による黑化の程度が基だ少い点, 又電顕像に括い てむ汗腺のものに比しや〉電子密度の低い点等から，人 の算腺獎液細胞に出現する lipoid 顆粒はかなり脂質の 量が少いものと思われる.

か〉る lipoid 顆粒は漿液細胞のみららず本論文では 詳迹しなからたが同時に観察された筋上皮細胞にも時に 出現する。

Lipoid 顆粒の基質には属々円形,無構造の大小の空胞 の出現を見る(図 12).乙れ恃岩井 (1958) が光顕的に認 めた Baker (1951) の lipochondria に一致するものと 思われ，又飯島 (1959) がヒトのエックリン汗腺におい、 て認めた電䫓像妃良く一致する所見である.

私の電顕像では lipoid 顆粒から lipochondria への 移行を想像せしめるような所見を認めたところから lipochondria は恐らく lipoid 顆粒から变化したものと 考光る.

又 lipoid 顆粒は属々自らの形を変じて不規則となり， その周囲に低電子密度の恐らくその内容物と思われるむ 
のを分泌している如き像を認める（図 4，9）.

〔C〕 細 胞 膜

人の籍腺倸液細胞の外周は細胞形質に比しかなり電子 密度の高い菲薄な単一膜構造によつてその外部と限界せ られ，所謂細胞朕の形成を見る。細胞が互いに密に隣接 するところでは两細胞膜の間には明るい間㗂があつて， 切断面では二重膜として認められる。

1) Microvilli (図 1,3,4)

人の奥腺將液細胞の腺腔面の細胞膜は常に平担ではな く, 細胞質の複雑な突起, 即ち他の多くの上皮細胞に見 られるるのと同様の多数の microvilli を有する.

Microvilli とは各種上皮細胞の遊離表面伦存する指状 の細胞質突起であつて Granger と Baker (1950)により 小腸上皮の小皮縁が microvilli より成ることが初めて 䉓子蝢改鏡で観察され，次いで Pease と Baker (1950) は腎尿細管上皮の刷子縁が microvilli よりできている ことを明らかにし，更に Dalton 等 $(1950,1951)$ ， Monroe (1953), Sjöstrand と Rhodin (1953) その他 の学者の研究で種々の上皮細胞の遊離表面炕 microvilli を有することが知られている。

私は人の鼻腺㝥液細胞の腺腔面において, 光顕的には 認められなかつた microrilli の存在を初めて確めた， microvilli の内部の 密度は細胞基質の密度と同一であ り，その内部には主部細胞基質と同㥞微細顆粒を有す る. 即ち microvilli は明らかに 細胞質の複雑な突起よ り形成されたものである.しかしその内部に分泌顆粒， mitochondria 等を有寸ることはない。

永腋細胞の microvilli 屾一般に指状で細長いものが 多いが時に短小で息肉状のものも見られる. microvilli は又分泌のいかなる時期の細胞飞る見られるものでな く, 分泌機能々密接な関保を有するものと思われ, 分泌 顆粒が細胞内に出現し始めた頃より現れ，分汹顆粒の增 量と共に microvilli は数と, 長さを增し所謂補充期か ら充盈期にかけて最む多く認められるが，分汹影粒排出 後の空虚期休止期の細胞には殆ど認められない，しかし 常に分汹機能と並行するとは云い難く，著しく細胞表面 の膨出した細胞相互の間隍及び細胞間分泌細管には極め て良く発達した microvilli を羿める（図１）。

2）細胞間嵌合と基底宿入

相隣接する 2 細胞の境界をなす夫々の細胞膜は一般に 極めて密に接して並走し，断面では 2 重膜として認めら れ，その間に狭少の細胞間隙を挾んでいるが，細胞間隚 は棘細胞等に見られる程著明ではない。
並走する雨細胞の細胞膜は平滑単純な走行を示さず゙複 雑に紂余曲折し，時にはS字状にあるい埂更に複雑に入 り組えで，夫等の細胞膜の間淿えヶの細胞形質を挾及込 てだ如き観を呈する部位を認める。

隣接細胞間のこのような入り組みは Pease と Balser (1950), Dalton (1951c), Weiss (1955b) 等によつて各 種の上皮細胞の境界面隹認められ intercellular inierdigitation or invagination と呼ばれたもので, 北村 (1958）は豚の肝腺飞和いて比の構造を細胞間嵌合と呼 えでいる。

人の鼻腺に括计る細胞間嵌合も, 上記諸学者の所見と 全く同様で一般に標めて明瞭である。

基底面に括ける細胞膜るまた複雑な走行を示するので あつて，筋上皮細胞，あるい恃固有膜に接する細胞膜が

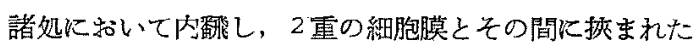
比較的電子密度の小なる琶から成る空隌形成する。 の 2 重膜間の架䧣は本来細胞外の空隐嘱するものであ る.この上うな基底部の細胞膜の複雑な樎入は最も良く 腎上皮細胞, 垂液腺の線条部に就いて認められ, Sjöstrand (1956)により B-cytomembrane, Pease (1955a, b) によつて basalinfolding あるいは Basalintussusception と呼ばれ，北村（1955）はこれを基底陌入と称した。

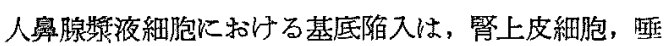
液腺線条部门おいて認められるもの程著明でなく，その 陷入も基底細胞膜は固有膜又は筋上皮細胞炕対して平行 に折り重つた形を呈し、その間に糸粒体の存在を認めな w.

基底陥入はその存在する位置からみて水分の吸收之密 接な関保が有るものと考光られている.

3）細胞間分泌細管

Schminke（1903）が初めて認めた 細胞間分泌細管は 獎液性腺管又は半月において認められる特有のるので, 粘液細胞間には泆して認められないと云う特異点から岩 井 (1958) は光顕的に繁, 粘液細胞の鑑別困難な場合に はこの細胞間分泌細管が一つの指標となると迹べてい る.しかし岩井はか」る分泌細管を明瞭涊める場合は 少かつたと述べているが，電顕的にはかなり明瞭に，又 雯タ認めることができた。

2〜3ケの細胞に囲まれた分泌細管の横断面では，各 細胞間に夫々明瞙な閉鎖是の存在を誌める、細胞間分速 細管の管腔内には腺腔面と同様に良く発達した microvilli を比較的多数認める.

4) 閉鎖堤及び desmosome（図 12,13)
$1-57$

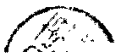


人の舆腺においても他の多くの腺細胞で観察されたも の之同様の構造を有する閉鎖堤 terminal bar の存在が 明瞭に認められる。即ち相降接する腺細胞の境界の腺腔 面直下部において，電子密度の高い紐状の構造物を認め ๖.

この部を詳しく観察すると，相隣接する 2 つ細胞の 細胞膜はこの部に和いて電子䍃度が極めて增加し, 平行 に走る短い 2 本の紐の如く見光る。その間には細胞間箵 を挾んでいるが，この部の細胞間隌は他の部に比し電子 密度はや>高い，更に電子密度の高いこの部の細胞膜か らは緗胞形質に向つてほよ゚直角に生えたヒゲのように徽 細な顆粒が集䅡して，その部のみ他の細胞基質より電子 密度高く，暗く見觉る。

この所見は Yamada (1955) のマウスの胆霍上皮， Weiss（1955）。十二指腸上皮，北村 (1958) の成の汗腺 等で見られた閉鎖堤の所見と全く同様である。

Weiss（1955）は閉鎖堤は細胞膜の密度之幅を增した むのとしておりり, Yamada (1955)，北村 (1958) は細胞 膜の電子密度の增加と，これに接する細胞質の局所的に 密度の增加したもので，細胞膜の幅の増加は見られない と述べている。

私が人㑭腺において観察した閉鎖堤において子細胞朝 の電子贸度の增加認めたが, 後述する desmosome に和ける如き細胞膜の幅の增大は見られず，前記 Yam$\mathrm{ada}$ ，北村等の所見と全く同様である.

更に相噒接する細胞の境界には閉鎖堤の近くで，その 基底部奇りに閧鎖堤と同様の構造を有する電子密度の高 、部位をいくつか認めることができる(図 12，13）.

この部を㹡大して見ると，電子密度の高い相対する 2 個のプレートと，それより細胞形質に向つて突出する多 数のヒゲ状構造から成り，このプレートは細胞膜が肥厚 し，電子密度の增大したものであり，その間にや>電子 密度の低い細胞間隌を塖んでいる. 又ヒゲ状の構造は閉 鎖堤と同様の徽細な顆粒の集種から成ることが判る（図 13).

この所見は人の皮歷及び口腔粘膜の基底細胞及び棘細 胞の細胞間橋に扟いて観察せられ，Selby (1955) Kよ $\eta$ constant diameter space, Porter (1953)により Bizzozeros node, あるい性 Odland (1958)により attachment zone と呼ばれたものと全く一致する。

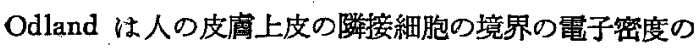
高いこの部を intercellular attachment zone と呼び, 前記プレート状の榡造を attachment plaques, ヒダ状
構造を tonofilament と呼び, 又 Maximow Bloom （1957）の成書炕プレート状の構造を bridge corpscle あるいは desmosome, ヒゲ構造を delicate, filament と記されている。

私もこつでは Miximow Blom の成書に従つて desmosome と呼ふことにする Selby (1955) は constant diameter space の電子密度の增加は細胞膜構成 Lipoid に Calcium が結合，多量に存しているためであるらと 考光ている。

このような陪細胞膜の限局性電子密度の堌加は人肝 細胞, ラッテ耳下腺腺条部上皮細胞, ラッテ吉田氏腹水 癌, マウス乳癌細胞等にる見出され, 高木 (1957)はこ れ等の構造が上皮細胞の結合をなす普遍的な構造である 万考文, Porter (1953), 'Yamada (1955) は閉鎖堤も 又同様のあのであらうと考えている.

私が人の鼻腺に扔いて観察した desmosome の構造 は前記諸学者の所見と全く同様であるが，閉鎖堤は一般 に desmosome よりるや〉長く後者に打ける如く練 胞膜の限局性肥厚, 即ちプレート様の構造は認められ ず、ヌヒゲ状の微細顆粒の集積も後者程著明でない。

(D) 核 (図 15)

核の細胞形質内における位置は分泌週期に応じて変化 する. 分必顆粒の認められない時期には細胞中央部近く に位置して正円形を呈し，核表面は䇣張して平滑であ る. 分泌機能が旺盛になると䇥は細胞基底面に近く位置 するようになり，その表面は凹凸不平で不規則な変形を 示すようになる. 恐らく分泌週期の循環と共に核の位 置形態も旧復するるのと思われる。

私は本研究に扣いて 3 枚の電顕像に 2 核の腺細胞を認 めた.かつる細胞は円錘形で大きく2核はいずれも紐胞 長軸に対し横に並び互に相近接して細胞基底部に位置し ている、1枚の電顕像で1核はほよ゙正円形で, 他はこ れに接して前者の外形に応じて压痕を作つている. 次の

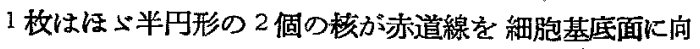
けて位置している。最後の 1 枚は 1 個の核は正円形で他 の核は撮影不手際のため一部のみしか見えないので詳練 は不明膫である。

1) 核質

鼎液細胞の核質は他の多くの細胞の核々同稼調密で， その電子密度は細胞基質よりや入大であり，細胞基質に 存するむのと同様微細顆粒がほら゙均等に分布している.

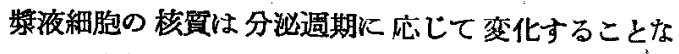
く、その内部の微細顆粒の増減は認められない。 
2) 㸖小体

核資内には核質上り更に電子密度の大なる不規則球形 の塊を時に見ることがある。これは即ら核小体で，核質 とは明眿に区別されるが，一般に明確な限界膜は認めら れない.

核小体の構造は Bernhard (1952), Horstman と Knoop (1957)，黒住と秋山 (1958), 玨川 (1960) 等に よつて研究され，その構造は微細顆粒の集合から成る紐 状の nucleonema から成つていると云われている.

しかし私の研究に和いては明瞭な写真を得ることがで きなからたので，その辀造に関しては詳細に述べること ができない。

3) 核 膜

核と細胞形質との境界には細胞形質よりや」密度の高 い核瞙が線状に認められる，

高倍率で観察すると，核膜は細胞質より電子密度大な る2林の膜之，その間吵に電子密度小なる無構造物を掞 んた 2 重膜構造から成る。核膜の外側膜にはその外側に 徽細顆粒が附着しているのが見られ，この顆粒は ER に 附着寸る細顆粒と，その大きさ及び電一密度の点で近似 する.

核膜が 2 重膜構造を有することは Callan と Tomilin (1950). が Triturus と Xenopas の精母細胞の核膜で 多孔性外層之，“造綕性内層とから成ることを明らかに L, Bariati $と$ Lehmann (1952) は Amoeba Proteus の分離核で, Harris と James (1952) は初めて切片像 でこの二重膜構造を実証した. その後多数の学者によつ て追試され，今日この事実を疑う者はない。

更に二重膜を貫く細孔のあることが Watson (1955) によつて各種の肧葉を起源する細胞核で示された。

又 De, Robertis (1954), Palade (1955b. 1956), Watson (1955)，黑住 (1957) 等に上り核膜の外側膜は ER 々同構造とされ; Bennett (1956), 渡辺 (1957) は 核膜より小胞体が形成されると考えている。

私も本研究においてかなり多数の核膜の細孔を認め， 又核膜外側膜が膨隆して ER と連続している像を認め た（図 15）。かる所見を見て直らに ERが核膜から形 成されるとる，あるいは又逆に核膜が ER より作られ るとす断定することはできないにしてる，このような写 真を示している学者の極めて少い点から䅭膜と ER の関 保を示す上に意義あるるのと解する。

第 節 分泌顆粒の形成機序

A) Golgi 野に出現する分泌顆粒

さきに式べた如く栖初期分泌顆柆は細胞内に殆ど，む
るいは全く分泌顆粒を誌めない、時期の細胞の Golgi 野 に管子密度のや」大，あるいはかなり大な緅密な物質を もつて名付けたるのである。

1) あるむのは極めて高い、電子辖度の円形小顆粒であ り、これは Golgi 顆粒の堌大したものと想像できるも のである(図2).

2）あるいは中等電子密度の不規則な形をした緅密物 質を認める、この物質は Golgi 膜の一端が膨大した如

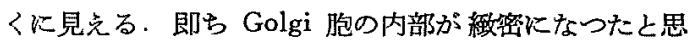
われるるのである（図，（）．この物質の顆粒化への移行 を想像し得る所見を得た（図 5).

3）あるいは文 Golgi 野内に位置する 層板状 ER の 中間に上記物貿を認める場合がある(図 11).

これら３つの場合いずれも著明な分泌顆粒への移行像 を認めた訳ではないが，これらの物筫が将来分汹顆粒に 転化するものと考えさるを得ない，

これらが分泌顆粒前段階物質でないとするなら，これ らの所見をいか考察すればよいか.

1) Golgi 顆稙が增大して高電子密度の 瞕調顆粒に転 化することは多くの学者の記載しているところで，私の 前記所見はこれに一致するものと考光る。

2)Golgi 胞の一部が膨化してその内部に分汹物質が蓄 穦すると考える学者もある所から私の第二の所見はこれ で説明できると思う。

この際の顥粒には一重の限界膜を認め得る。

3) Golgi 野内で ER の一部が顆粒化する考え方は従 来との記載を見ないところである.しかし私の所見では Golgi 野内に明らかに不完全乍ら層板状の ER を認め るし，この ERの中間域において限界膜に包まれた不 規則の形乍ら第二の所見に見られた如き物貿を認めると ころから，か〉る顆粒形成も否定できないのと考え る.

以上の事から，分泌顆粒の前段階物質と考㝋られるむ のは、いずれる Golgi 野に括いて産生されることが判 る. しかし常に一定の小器官から産生されるとは限ら ず, Golgi 顆粒, Golgi 胞, Golgi 野内の ER のいず れからも産生されるのであるらと考党る。

B）糸粒体より耘化する分汹顆粒

細胞内に著明な分汹顆粒がかなりの量出現する時期に おいては通常からる前段階物質は最早認め得なくなる。

光顕的江同定し得た分速顆粒は明らか沉胞膜の外側 にあつて細胞形質基質内に位置している事が判る. 即ち か〉る分泌顆粒は ER の小胞腔内には位置しない。 
細胞先端部に㷛積した分速顆粒を見るに，屡々その顆 粒内に空胞の出現するものがある.空胞内には梁があ る.これは一体何を意味するものであろうか。

図6枠内の分泌顆粒は内部に空胞状構造を有し，その 空胞の大ささは汪ら゙糸粒体と同大で，究の限界膜は不明 睧乍ら 2 重膜構造を有し，その matrix は糸粒体に比し 明調である。その内部にはや>電子密度の高い網状の梁 を認める。この梁恬限界膜から発し且つ二需膜棈造を示 すところから，㐘粒体に類似の構造を持つものと考えら れ，恐らく糸粒体の matrix 中の細顆粒が，糸粒体の 内部梁及び限界膜内側に沈着したものであううと私は想 像する.から内部梁俚正常の禾粒体に比し著しく不規 則な形態を示している.上記分釆顆粒はかっる変性した 糸粒体の限界膜外周に更に細胞形質基質中の Palade の 顆粒が沈着して形成されたものであろうと䒓える.

かつる分泌顆粒の限界膜が不明膫な点, 又分必顆粒の 韯面に微細顆粒を認好点, 更に分泌顆粒の多数出現し ている部位では米粒体が少ない点からも米粒体から分速 顆粒への転化が首肯できる.

従つて以上の所見から私は萝腺獎液細胞の分泌顆粒は 極初期には Golgi 野から 産生され，その後は特に細胞 先端部においては糸粒体から転化するるのがあると考え る.

\section{第IV 章 総括及び考按}

電子顕微鏡に上る細胞学的研究は超薄切片法, 固定技 術の向上と共に数年来箸しい進歩を遂げ、動物各種組織 細胞の基本的微細構造が次第に明らかになつてきた。腺

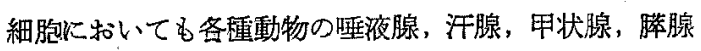
細胞等の電子顕微鏡的研究により, 従来光学䫓微鏡では 得られなかつた新知見が多数得られるよらになつた。し かし未だ人の䒜腺の電子顕微鏡的微細構造並びにその分 泌機構についての研究は行われていない。

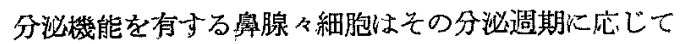
桠めて複雑微妙な形態的変化を示すむので, 岩井(1958) は光学顕微鏡により人の學腺の形態学的研究を行い, 初 めて米粒体，Golgi 装置を中心としての分泌機序の解明 を行つた、しかしこれは光学顕微鏡の分解能の範囲内で あつて，稩胞の微細構造の変化については述べていな i.

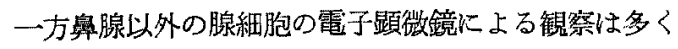
の学者によつて行われれているが，これとてもその分必 造期に応ずる微細構造の変化について述べているるのは 極めて少ない。

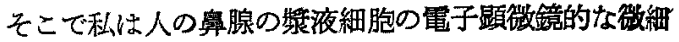
搆造の分泌週期応ずる変化と, 分脑顆粒の形成機序を 明らかにしよらと試みた。

1) 分泌週期に応ずる細胞の変化

岩井は光顕的に番腺々細胞の分汹週期を次の 4 期に分 けた. 即ち分必顆粒の全く認められない空虚な休止期, 分泌顆粒が出現して細胞先端部に集喘する裐充期，更に 細胞全面に分泌顆粒の充盈する充盈期，やがて分汹顆粒 の排出される排出期である.

しかし電顕的にこれを観察すると腺細胞の内部構造仕 分泌機能の状態に応じて余りに複雑微妙な変化を示し, 岩井の分類した如く，4期に分けて説明することは甚た 困難である。

1) 分泌顆粒出現の極初期：細胞は円柱状て核は細胞 のほぶ中央に在り円形である．核周团，特に核下部には 著明な啳板状の $\mathrm{ER}$ が認められ核上部には又層板状の 馬蹄形を呈した Golgi 体を明瞪仁認める．Golgi 野の 内部には Golgi 体から移行し 分速顆粒の前段階と考兄 られる顆粒が少数現れている。糸粒体は長桿状, 桿状の 興型的なものが細胞の全面に分布している．細胞基貿に は脰富な Palade の顆粒が一椂に撒布して, 細胞は全体 としては暗調である。

2）分泌顆粒が Golgi 野及び核側部にや小增量してく ると核はな和正円形のま入細胞基底部へや」低下してく る、核下部に著明に見られた層板状の ER はとの層板 状構造を失うようになる。かつる ER の变化は盾村 (1959) のピロカルピン注射後の耳下腺細胞の所見上一 致する，米粒体の形態及びその数量には大した変化は見 られない。

3）分泌顆粒が增大して核上部に集筫する時期，即ら 岩井が光顕的に補究期と称する時期になると細胞は一般 にや〉膨化の傾向を示し核は時汇変形を示す場合るある がな招一般には円形を保つている。しかし核の表面は平 滑でなく小凹凸あるいは小波状を呈している. Golgi 体 はな拉良く発達した算板状構造を示しているが，ERは その層板状構造を失い断片状となり細胞内に敞在するよ うになる。糸粒体は核上部特に細胞先端部では殆ど認め られないが，核側部，核下部ではなお正常の形を示して いる。

4）分论顆粒が細胞全面に 充盈すると細胞は著明に脰 大し核は基底面に接して位置するょらになる，核の表面 には凹凹を認めるが強く変形したり，濃縮傾向を示すこ とはない. 核におけるこの所見は光学顕微鏡による岩井 
の所見とよく一致する.

Golgi 体は細胞周辺部に圧排されるようになり屡々圈 板状構造を失い，不明膫となる．ER るまた極めて断片 的で不明暸である. 米粒体は時に分泌顆粒の間代認め得 ることもあるが核上部では甚だしく減量の傾向を示して いる。

5）分汹顆粒を殆ど,あるいは全く認めない細胞で ER の小胞腔が膨化し，胞状不規則な形態花示するのがあ る. 胞状の ER は細胞の大部分を占め, それらの間の 細胞基質はために綢状となる. Palade の顆粶は隇量し， ために細胞は淡明となり，膨化した釆粒体を認める。か

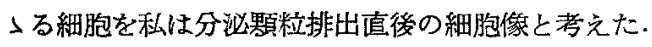

6) 細胞内に分泌顆粒む胞状 ER も全〈認めず，糸粒 体は興型的形態を示すが，その長さを增し長桿状のもの が多い細胞に遭遇する．その細胞基質は低電:密度で比 較的淡明である．ER は断片状で細胞全面に分布し，時 炕は不完全乍ら榕周囲に層板状構造を示寸るのがある.

か入る細胞を私住分泌顆粒排出後次第に分泌前期の細 胞へと回復しつつある時期のるのと考克，これを分泌休 止期の細胞と考えた.

分泌休止期の細胞が分泌週期の最終段階とするなら， この細胞はやがては分泌顆粒出現の極初期細胞一と移行 し，分泌違期を一巡するものと思われる.か子る分泌週 期の一巡を明確に証明した文献に私は未だ遭遇しない。 岩井 (1958) の光顕的研究において子分议顆粒排出後, 再び分泌開始に到る間の時期に就いては充分の観察が行 われていない，しかしこれは光学顕微鏡の限界であつ $\tau$ ，電顕的にの及観察し得るところと思われる.

2）分脑顆粒の形成機序について

腺細胞に和ける分议物の形成が細胞内のいかなる場に

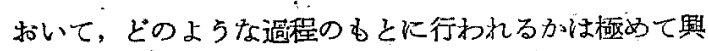
味ある問題で，従来各種腺細胞について研究されている がその見解は色々である。

電子顕微鏡により Golgi 装置が分泌顆粒の形成に 関 与すると云5学者には Rinehart と Farquhar (1953), Sjöstrand $z$ Hanzon (1954b) Moussa (1956), Rhodin $\measuredangle$ Dalhamn (1956), Farquhar $z$ Wellings (19 .57)，渡辺 (1959) その他がある.

しかしこれ的対する学者す有り, Bronnettaと Daniel (1959), 入江 (1960) 等は耳下腺, 甲状腺に括いて 夫々西者の間に密接な関倸はないと述べている。北村

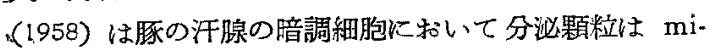
crosome より直接又は Golgi 䧇置を介して形成される
と考学ている。

$\mathrm{ER}$ から分必顆粒ができるとするものも多数あり， Weiss (1953) は蓃腺細胞の Zymogen 顆粒は ER の 小胞腔内でできると述べ, Palade (1956) 毛膵腺細胞の ER から分谈に関倸ある顆粒が形成されると述心てい る. Dempsey と. Peterson (1954), 王 (1958), 藤田 （1958）等は甲状腺細胞に打いて同様の見炤を述へてい、 Ђ.

一方米粒体から分泌顆粒が形成される上する学者には Challice \& Lacy (1954), Lever (1955. 1956), 小野巧 等 (1957), 北村 (1958), 飯島 (1959), 艺の他がある.

岩井 (1958) は光学顕微鏡下に人與腺の槳液細胞は分 泌顆粒の增加と共に米粒体の減少するところから，分泌 顆粒は米粒体からできると述べた。

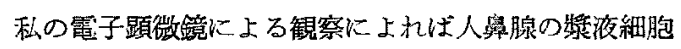
の分泌顆粒形成には先きに述べた如く二样の形成がある ものと推察される。

即ち (1) Golgi 野内で形成される分泌顆精上 (2) 系 粒体と Palade の顆粒 (RNA 顆粒) とから形成される 分泌顆粒とである.

(図2）の Golgi 野内に見られる高電子櫁度の顆粒は 極めて初期の分泌顆粒で，その大きさ，電子密度及び位 置的関係から Golgi 顆粒が增大したものて，分汹顆粒 に転化する前段階のるのと考える。

(図5，10) に执いては Golgi 顆粒之同大のものから 分泌顆粒に䎐化したもの迄の種々相が見られ，それ等は や入不鮮明乍ら一重の限界膜を認める。これは Golgi 膜の一部が膨化してその内部に分泌成分が蓄䅡して顆粒 化するものと思われる所見である。

又 (図11) では Golgi 野的に位置する層板状の ER の中間位置江不蟹明乍ら限界膜を有主極初期の分泌顆粒 を認める。

以上の所見から私恃人鼻腺の分泌極初期の漿夜細胞に おいては，分必顆粒は Golgi 野内で形成されるものに 相違ないと考える。しかしそれが Golgi 顆粒から直接 移行するるのであるか，Golgi 膜の一部が膨化して，そ の内部に分汹物成分が貯溜せられるもので方るか，ある いは Golgi 野内の ER が分泌顆粒に㴶化寸るものであ るかを早計に断定することはできない，恐らくは上記三 様の方式があるのではないかと㨅える。

又分泌機能旺盛な充盈期の細胞を見るに紐胞先端部に

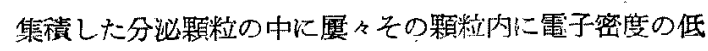
い，明る〈抜けた空胞样の構造を認める(図6)，その 
大き志は活ぶ栄粒体之同大で，時に明瞙な二重膜の限界 膜を有しその matrix は糸粒体に比し明調である.その 内部にはや〉電子密度の高い不規則な線様構造があり, 時に米粒体之同様の 2 重膜構造を有寸るるのが認められ 米粒体内部梁と類似の構造を示寸ところからその遗残物 と考える.かつる構造を有する顆粒は糸粒体が変性し, 系粒体内部梁が崩壊して限界膜内側に沈着すると同時に 更に糸粒体外周に細胞形貿中の Palade の顆粒 (RNA 顆粒）が沈着して形成されたものであるらと思われる。

伊東等 (1951) は人のフポクリン汗腺で分泌顆粹が RNA の㩐い被膜によ゙り包まれて扔り，分泌顆粒の成熟

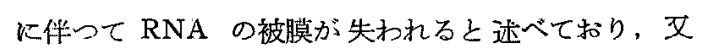

Tamaki と Iwashige (1950) む同様に人の膵外分泌腺 細胞において迹べている.北村 (1958) は眽のニックリ ン汗腺の明調細胞において電顕的にこれと一致する所見 が多いと述べいるが，上記の如く私の電顕像で糸粒体の 外周に Palade の顆粒即ら RNA 顆粒が 附着している 所見は伊東等が認めた未熟分必顆粒の 被膜が RNAで ある々云う点湮めて良く一致するものと考光る.

私の所見で分泌影粒の排出後, 細胞基貿以 Palade の顆粒が減少して淡明になり，糸粒体もまた減少する点 は分泌顆粒が RNAの被膜を持つ米粒体であると寸れ ば容易に理解できるところである.

この上らに人鼻腺の漿夜細胞の分必顆粒は分必初期に は Golgi 野から形成され, 分速機能の旺盛な 補充期, 充盈期にかけては糸粒体と RNA 顆粒とから形成され ると思われ，要 (1960) が述べている如くその形成機序 は一元的なものではないと考える.

3) LiPoid 顆粒及び lipochondria

上皮細胞に脂肪滴が出現することは光学顕改鏡的に多 くの学者によつて㐨告せられている。

横地 (1954 b) は人食道腺の排泄管上皮細胞, 腺細胞 に怙いて，岩重 (1952) は人のエックリン汗腺細胞にお いて高年者では多数の有胞性脂肪滴が現れ，反対に Golgi 装置の発達が悪くなるのを認め, Golgi 荘置の脂肪 化と唱光た．伊東と渡 (1958)は人の膵臓の Langerhans 氏細胞泫打いて，Baker (1951) の liPchondria 一致するる無胞性あるいは有胞性脂肪小体と Golgi 装置 之の間に移行があり, 脂肪小体が Golgi 装置から形成 されるのを見出し，岩重の Golgi 装置の脂肪化説を承 認した。

岩沚（1958）は人の鼻腺々細胞に拈いて無胞性・有胞 性の脂肪滴を光顕的に認め,これが Baker の Lipocho- dria に一致するものであろうと速ぺている.

飯島(1959)はヒトの腋窝エックリン汗腺の電子㩆微镜 的観察により多房性の脂肪滴は Baker の lipochondria に一致するるのでその発生源は恐らく Golgi 顆粒であ ろらと述べている。飯島の研究によればその成熟したる のは周辺们高電子密度の限界膜をもち, 内部の電子密度 はこの限界膜の電子密度よりゃ」低い，限界獏の表面は 通常平滑であるが，時には世凸不平の場合もある，文の 最も特徵ある点は lipochondria の内部に $50 \mathrm{~m} \mu \sim 0.5 \mu$ の大小不同の多数の空胞を含友泡沫状外氍を呈すること である、架胞自身も多く球状で平滑な膜に゙より境せられ ている.

lipochondria は 1 個，時に 2〜3 個集合して存在し， 核の上部に接して発見されることが多いが基底細胞では。 時に核々無関保沉存在する。

lipochondria の内部空胞は次第に增大し, 空胞相互 に融合して遂住 lipochondria 内部全体に拉り, 高電 子密度の部分は lipochondria の限界膜と空胞外周老囲 む膜のみとなり，最終的には限界膜の一部が破綻して， そこから内部の空胞は細胞質中に脱出し, 移行すると述 ベている.

私の所見に执いても飯島の所見と全く同様であり，又

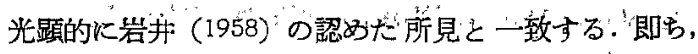
無胞性のものは lipoid 顆粒, 有胞性のものは lipochon dria と同定した. そして私は lipochonria は lipoid 顆 粘から変性したものと相像している.

しかし飯島が汗腺に認めているるのと此較して電子密 度のや〉低い点, 艾光学影微鏡下に扣いてすオスミウム 酸による黒化の程度の甚だ少い点等を考えて, 人の鼻院 腺細胞に出現する lipoid 顆粒及び lipochondria は他の 上皮細胞に見られるものよりはかなり脂質の含有量が少 いものではないかと考党ている。

lipoid 顆粒及び lipohondria は分泌週期の 各時期に 認められ，又筋上皮細胞にも認められる。

\section{第 $\mathbf{V}$ 章 結 語}

人の鼻腺獎液細胞を電子顕微鏡的に観察して次の結果 を得た。

（1）細胞は分泌機能時期に応じて複雑微妙な形態的变 化を示寸

分淧顆粒出現の極初期には核はほら゙細胞中央位にあつ て正円形で，核下部には豊富な層板状の ER，核上部に は良く発達した層板状の Golgi 体を認め，糸粒体は典 型的形態を示し細胞全面に垃等に分布する. 
分泌顆粒が出現し，增量すると次第に核は基底部一低 下L，変形し，ER，Golgi 体は噟板状抍造を失い，不 明膫となる，充盈期には糸粒体は膨化し娍少の傾向を示 + .

分泌顆粒排出值後は RNA 顆粒乏しく，ER は膨化 し胞状となり，系粒体は少量で著しく膨化している。次 いで胞状 ER は密集性となり細胞内部は一見網状を呈 し、夈粒体は堌量し始める. 更に RNA 顆粒が增量し て ER は压縮され，不完全な噟板状を呈して分必前期 の細蚫となる。

（2）分泌顆粒は極初期には Golgi 野で形成され，Golgi 顆粒, Golgi 膜, Golgi 野内の ER のいずれから も形成されると思方れる。

補充期から充盈期にかけては主として核上部で, 変性 几た糸粒体の外周に RNA 顆粒が附着して形成される と考えられる。

(3) Baker の lipochodria を認め, lipoid 顆粒, lipochondria は分汹週期の 各期に認められ，箈上皮細 胞にも諰るられる。

（4）核膜の外側膜が ER に移行する像を認めた。

（5）細胞間に光顯像では全く認められなかつた desmosome 及び閉鎖堤を認めた，両者の構造は極るて類 似しているが，多少の相違のあることを知つた。

（6）腺腔に面する 細胞遊離縁には microvilli が存在 する. microvilli は細胞の分泌機能に応じて変化するも のである.

（7）細胞管分汹細管を屡々認めたその管腔内には豊 富な microvilli が存在する。

（8）薮接細胞の境界には著明な細胞問嵌合を，紶胞基 底部には基底陌入を認める。基底陌入は量液腺々条部細 胞，腎上皮細胞程著明ではない。

\section{文献}

1）新井元吉：腎細尿管上皮細胞内小管と Mitochondria に就いての電子顕砫鏡的観察・解剖誌, 32 (1957) 頁 159. 2) Bargmann. W.,: Histalogie und mikroskropische Anatomie des Menschen. S. 489 492 (1956). 3) Baker, J. R.: The structure and chemical composition of the Golgi element. Quart J. Micr. Sci. 85, 1 71 (1944). Further remarks on the Golgi element. Quart. J. Micr Sci 90. 293 307 (19 42). the Golgi Substaoce, Nature. 168. 1089 1090 (1951). 4) Bariati. A., Lehmann. F. E.: Exper 8: 60 (1952). (電子影微鏡の理論と応用・電顕学会編
(1959）より引用).

5) Bennett. H. S.: The concepts of membrane flow and membrane vesiculation far active transport and ion panping, J. biophy. biochem. cytal. 2 (1956) P. 99 104. 6) Bernhard. $W . F$. Haguenau et ch. Oberling: L ultrastructure du nucléale de quelques celles animales rèvéllèe par le microscope electronique Experientia, 8 (1952). P. 58 59. 7) Bernhard. W., A. Bauer Gropp. F. Hagaenau et ch Oberling: L' ultrastructure du mucléale de cellules et cancèreuses. Exp. cell Res. 9 (1955). P. 88 100. 8) Bernhard, W. and C. Rouille: close topagraphical relationship between mitochondria and ergastoplasm of liver cell in a definiti phase of cellular activity, J. biophy. biochem. cytol, 2 (1956). suppl. P. 73 78. 9) Bronnetta. L. S. and Daniel, C. P.,: Electron microscopy of the salvary and lacrimal glands of rat. Amer. J. Anat 104 (1959). P. $115 \sim 161 \quad$ 10) Callan, H. G., Tomlin, S. G., Proc. Ray Soc. London. 137. 367 (1950), (電子顕微鏡の理論と忘用 (II) 電影学会編 (1959) より引用). 11) Challice, C. E. and P. Lacy,: Nature 174 (1954). P 1150

Dalton. A. J.,: Observation of the Golgi substance with the electron microscope. Nature. 168 (1951 a) P. 244 245. Electron micrography of epithelial cells of the gastrointestinal tract and pancreas. Amer. J. Anat. 89 (1951 b). P. 109 119. Structural details of some of the epithelial cell type in the kidney of the mouse as revaled by the electron microscope J. Natl. Cancer Inst 11 (1951 c). P. 1163 1169.

13) Dalton, A. J., H. Kahler, M. J. Striebich and B. J. Lloyd,: Fine structure of hepatic intestinal and renal cells of the mouse as revealed by the electron microscope. J. Natl. Cancer Inst 11 (1950) P. 439 461. 14) Dalton, A. J. and M. D. Felix,: Studies on the Golgi substance of the epitherial cells of the epidiymi and duodenum of the mouse, Amer. J. Anat: 92 (1953): P. 277 305. Cytologic and cytochemical characteistics of the Golgi substance of epthelial cells. J. Histochem. Cytochem. 2 (1954), P. $241 \sim 345 . \quad$ 15) Denker and Kahler,: Handbuch der Hals-Nasen-ohren heilkunde Histologie d. Luftwege und d. Mundhölhle, von Schumacher. 1 (1925), P. 299 300. 16) Dempsey, E. W. 
and $R$. P. peterson: Endocrinology. 56.: 46 (1954) 17) De Robertis, E.: The nucleo-cytoplasmic relationship and the basophilic substance (ergastpplasm) of nerve cells. J Histochem. Cytochem. 2 (1954). P. 341 345. 18) Farquhar, M. G. and S. R. Wellings: Electron microscopic evidence suggesting secretory granules formation within the Golgi appartus. J. biochem, cytol. 3 (1957). P. 319 322.

19）藤田尚男・加納㓐已。木户考夫：日組鑔，14(1958).

20) Gansler, J. et Rouiller, ch.: Schweiz. Zschrall, Path Bakt. 19: 217 (1956).（渡辺陽之輔：電子頙微鏡 に上る病理学的研妴の進步・綵合臨牀? 巻 8 号 (1958) 真 75 より引用). 21) Granger, B. and R.F.Baker,: Electron microscope investigation of the striated border of intistinal epithelium. Anat. Rec. 107 (1950). P. 423 442, 22) Harris, P., James, $T$. W.,: Exper, 8. 384 (1952). 22) Harrii. P., James, T. W.: ExPer, 8. 384 (1952). (電子顕微鏡の理 諭と応用 (II) 電影学会編 (1959) より引用). 23) Hirschler，J. (1927)：（伊東俊夫・ゴルヂ装置の棈造 に就いて一特にヒルシュ氏説 (Hirschsche Systhemtn-

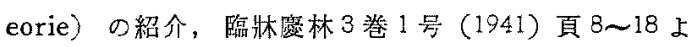
り引用). 24) Horstmann, E. u. A. Knoop: Zur Struktur des Nuclealus und des Kernes. Z. Zelforsh. 46 (1957) S. S. 100 107. 25) 岩半広方：人番腺の 形態学的研究, 日耳睤会報 61 巻 9 号 (1958) 頁 1454 1472. 26）伊東俊夫：ゴルヂ装置の棈造について一特 にヒルシュ氏颜(Hirsch'sche Systhem theorie)の紹介, 臨牀度林 3 巻 1 号 (1941) 面 $8 \sim 18$, 人類皮膚に持ける エックリン汗腺の細胞学的研究, 特にそのアポクリン性 分泌就いて，医学と生物学 6(1943) 頁 80〜83. 27) 伊東俊夫・土屋和子・些重毅：汗腺細胞に括ける塩基 好性物質 (リポ核酸) の研究，日組録 2 (1951) 頁 279 〜287. 28）伊東俊夫 - 渡仲三：人の膵藏 Langerhans 比島細胞の Golgi 装置に就いて，日組録 14 巻 3 号 (1958)，29）岩重效：健康な高年者の腋凰エック リン汗腺の細胞学的組耭学的研究, 日組録 4 巻 1 号 (19

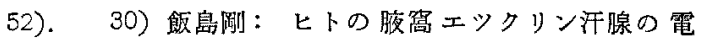
子顕微鏡的研究, 解剖誌 34巻 5 号 (1959) 頁 645 672. 31) 入江正昭：哺乳類甲状腺の電子顕微鏡的研究, 日 組録 19 巻 1 号 (1960) 面 39７4. 32) 黑住一昌：卵 緗胞微細棈造の電子昰微鏡的研究, 解剖誌 32 (1957 a)

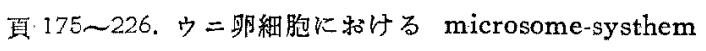

について（光学及び電子顕微鏡的钼察）電子影微鏡 6

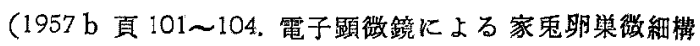
造の政究, 北関東医学 7 (1957c) 頁835. 33) 㫮住一 昌・高橋嘉幸・渡迢昭：鯉の搼缄外分泌細胞に战ける intracisternal granules について，電子顕微踥 8 (1959) 面 48. 34) 黑住一昌・北村辰郎・㕰島阔：エックリ ン汗腺分泌部の電子湿微鏡的研究，電子影碳镜 7(1959) 頁 120. 35) Kurosumi, K. and T. Kitamra, Occurence of faldings of plasma menbrane ( $\beta$-cyto menbran) in cells of pigs carpal organ as revealed by electron microscopy. Natare. 181 (1958). P. 489. 36) Kurosumi, K., T. Kitamura and T. Iijima: Electron microscope stadies on the human axillary apocrine sweat glends, Arch. hist. jap 16 (1959) P. 523. 37) 黑住一昌・秋山洋一：核小体の超微細構造 について, 日組録 14 (1958) 頁 291〜307. 38) 北村 辰郎：豚の手根器官 (Carpal Orgam) の電子顕微鏡 的研究. 日組録 14 (1958) 真 575 610. 39) 要真一 朗：人胎児汗腺の電子湿微鏡的観察, 日組録 19(1960) 頁 215 239. 40) Leuer, J. D..: A mer. J. Anat, 97 (1955). J. bioph. biochem, cytol, 2, suppl 3. 13 (1956). 41) Maximow, A. A. and W. Bloom: A textbook of histology, 7th, Ed. (1957). 42) Moussa, T. A.,: The Golgi apparatus and secretion of enzymes in peptic cells of rabbit. Natue. 178 (19 56) P. $1002 \sim 1003$. 43) Mourac, B. G.: Electron microscopy of the thyroid. Anat. Rec. 116 (1953). P. 345 . 44) Odland, G. $F$.,: The fine structure of the interrelationship of cells in the human epidermie. J. biophys biochem cytol 4 (1958). P. 529 538. 45) 王竜三：電子顕微鏡 6, 184 (1958). 46) 小野江為則 - 森田栄 - 提鎮男 - 高橋 媤行 - 室谷光三: 変性及び增殖に際する細胞微細構造の電子影微鏡的研究 (II) 肝細胞の変性及び再生に関する細棈造の変化, 電子顕微鏡 6 (1957). 面 $111 \sim 115$. 47) Palade, $G$. E.: A study of far electron microscopy. J. exp. Med. 95 (1952a). P. 285 297. The fine structure of mitochondria. Anat. Rec. 114 (1952 b) P. 427 452. An electron microscope study of the mitachondrial structure. J. Histochem. Cytochem. 1 (1953). P. 188 211. A small particulate component of the cytoplasm. J. biophy. biochem, Cytol, 1 (1955 a). P. 59 68. Studies no the endolasmic retictlum. II 
Simple dispositions in cellin in situ J. biophy, bio. chem, cytol. 1 (1955b). 567 582. Intracisternal granules in the exocrine cells of the pancreas, J. biophy. biochem. cytol. 2 (1956) suppl P. 85 97.

48) Palade, G. E. and K. R. Porter: The endoplasmic reticulum $I$. Its indentification in cell in situ. J. exp. Med. 100 (1954) P. 641 656. 49)

Pease, D. C.: Electron microscopy of the structure of the kidney cortex. Anat. Rec. 121 (1955a). P. 723 743, the fine structnre of the kidney seen by electron microscopy. J. Histochem. cytochem. 3 (19 55 b). P. $295 \sim 308 . \quad 50)$ Pease, D. C. and R. E. Baker,: Electron microscopy of the kidney. Amer' J. Anat. 87 (1950). P. 349 389. 51) Porter, K. R.,: Observation on a submicroscopic basophilic component of cytoplasm, J. exP. Mec. 97 (1953). P. 727 750. 52) Porter, K. R., A. Claude and E. F. Fullam,: Study of tissue culture cells by electron microscopy J. exp. Med. 81 (1945) P. 233 246. 53) Poter, K. R. and H. P. Thompson,: Some morphological features of cultured rat sarcoma cells as revealed by the electron microscope. Cancer Research. 7 (1947). P. 431 438. 54) Rinehart, $J$. $F$ and M. G. Farpuhar: Eleotron microscopic studies of the anteriar pituitary gland, J. Histochem Cythchem. 1 (1953). P. 93 113. 55) Rhodin, J. and $J$. Dalhamx. Electron micrescopy of the tracheal ciliated mucosa in rat. Zellfarsch. 44 (1956) S. 345 412, 56) Schmincke, A.,: Zur Kenntnis der Drüsen der menschlichen regio respiratoria. Arch. f. mikr. Anat. 61 (1903) S. 233. 57) Selby, C. C.,: J. of biochem, Cytol I (1933) P. $429 \quad$ 58) Sjöstrand, F. S.: Electron microscopy of mitochondria and cytoplasmic double membranes. Nature 171 (19 53). P. 30 32. Electron microscopy of cells and tissues. physical Techiniques in Biological Research, Vol. 3. P. 241. Academic Press, New york. 1956. 59) Sjöstrand, F. S. and J. Rhodin,: The ultrastructure of the proximal convoluted tubules of the mouse kidny as revealed by high resoluti on electron microscopy. Exp. cell Res. 4 (1953). P. 426 456. 60) Sjöstrand, F. S. and K. Hanzon,: Membrane structure of cytoplarm and mitochondria in exocrine cells of mouse pancreas as revealed by high reslution electron microscopy. Exo. cell Res. ? (1954 a). P. 393 414 Ultrastracture of Golgi apparatus of exocrine cells of mouse pancreas, Exp. celf Res. 7 (1954c). P. 415 429. 61) Stöhr, Ph., Ueb. d. feiner, Bau d. respir, Nasenschleimhaut, Beitr $Z$. mikrosk, anat. zu menschl, Körp. Verh. d. phys. med, Ges. zu Würzbury, Bd. 20. I. S. 5 7. 1886, Lehrbuch der Histologie und der mikroskopischen Anatomie dcs Menschen, S. 30. 1887. 62) 坝口弘-

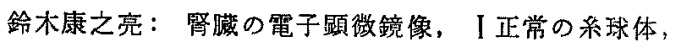
綜合医学 15 球 9 号 (1958 a) 頁 672 680. 【正常の尿 細管, 綜合医学 15 巻 10 号 (1958b) 頁 747 760, II 腎 炎の系球体变化, 綜合医学 15 巻 12 号 (1958c) 真 870 〜880. V尿細管の变化, 綜合医学 16 巻 3 罗 (1958) 頁 290 303. 63) Tamaki, u Irvashige.: Zytalogische Untersuchungen des menschlichen pankreas. Okajamas FoliaAnatomica japonika. IBd. 23 (1950). (伊" 藤 etc：日組録 2 巻 3 号 (1951) 上り引用). 64) 高

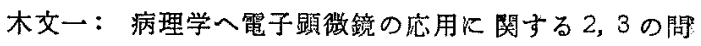
題, 綜合医学 14 巻 7 号 (1957) 頁 635 . 65) 種村百 代：耳下腺組織の電子顕微鏡的研究，第 I'編，第 II編， 金沢大学医学部解剖学教室業蝜, 58 (1959). 66) 五 川健二郎：正常及び実験的レーリ一現象に括沙るモル モット上頸部交感神経節の電子㩆微鏡的研究, 日耳会 報, 63 巻 4 号 (1960) 面 978 994 67) Watson, $M$. L...: The nuclear envelope, Its structure and rela-. tion to cytoplasmic membrancs. J. biophy. biochem.. cytol. I (1955). P. 257 269. 68) Weiss, J. M: The ergastoplasm, its fine structure and relation to. protein synthesis as studied with the electron micr-oscpy in the pancreas of the Swiss albino mouse. J. exp. Med. 98 (1953). P. 607 618. Intracellular changes due to neutral red as revealcd in the pancreas and kidney of the mouse by the electron microscope. J. exp. Med. 101 (1955a), P. 213 224. The role of the Golgi complex in fat absorption as studied with the electron microscopy with observation on the cytolgy of duodenal absorptive cells. J. exp. Med. 102 (1955b). P. 775 782. 69) Wallace, $H$. C. and Richard, G: H.: Electron microscopy studies of the human epidermis the clear cell of masson (Dendrite cell or Melanocyte). J. biophy. bio- 
, chem. cytol. 4 (1958). P. 679. 70) 渡辺陽之輔：

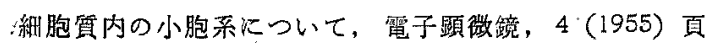
89 91. 細胞の電子顕微鏡的基本梅造, 綜合医学, 14 (1957) 頁 649 662. 電子频微鏡の理論と応用 1，電子

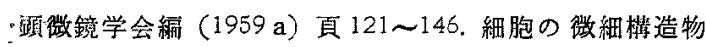
とその㙨能に関する最近の知見 (小胞体), 日本の医学 ，の1959年，第 15 回日本医学会総会学術集会記緑第 1 乲 $\therefore(1959$ b) 頁 77 ～86. 小胞体について, 生体の化学 11 资 -1号 (1960) 面 $2 \sim 12$. 71) 䅦地千仅：人腸粘膜の絊 ; 胞学的研究 III，十二指腸腺について，日組録 2 巻 1 号 . (1954 a).人の食道腺の細胞学的研究（人の食道腺は粘 、液腺かあるい混合腺か) 日組録 6 巻 2 号 (1954b)，

72) Yamada, E.: The fine strncture of the gall bladder epithelium of the mouse, J. biophy. biochem. -cytol 1 (1955). P. 445 458.

\section{付图説明}

付图 1: 漿液性腺管 $\times 3,900$

腺腔を围む細胞には分泌週期の諸相が見られる。稩胞 と紐胞の間に細胞間分泌細管が明瞭に認められる。

付図 2：分泌顆粒出現の極初期の細胞 $\times 9,000$

核上部に馬踣形儿嶈曲した層板上の Golgi 膜が見ら :れ、これを囲むGolgi 野内に高電子密度の極初期の分泌 顆粒を認める。核下部には著明な㬝板状の ERを認める。

付図 3: 分泌顆粒出現時の細胞 $\times 9,000$

核上部の Golgi 野及び核側部に数ケの分泌顆粒を認 める。核側部には ER がな㧤層板状を呈して配列す る.は心゙正円形の核には核膜細孔が著明に見られる。細 胞膜には閉鎖是，細膜間嵌合が見られる。

付図 4：分泌顆粒補充期の細胞 $\times 9,000$

一細胞先端部には高電子密度の暗調分泌顆粒, 核との中 “間域には中等度電子密度の中間調分泌顆粒を認める。 Ｇolgi 体はな稀板状棈造を保持するも，ERは不熊明 で断片状に見れる。

付図 5: 分泌顆粒補充期の細胞 $\times 9,000$

Golgi 野内と, 細胞先端部に分泌顆粒の集皘を見る。 Golgi 膜は典型的な馬蹄型の層板状を呈する。

付図 6：分泌顆粒充盈期の細胞 $\times 9,000$

細胞は分泌顆粒で充盈されている.これ等の分必顆粒 は中等度電子密度の中間調顆粒が多く, 㑛々内部が空胞 状に見えるものがある.これは糸粒体及び RNA 顆粒

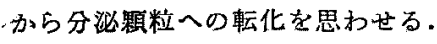

左下侬内の顆粒には空胞状の内部に系粒体内部梁の遗 残物と考えられるものが見られる。
付図 7：分泌顆粒排出直後の細胞 $\times 24,000$

ER は膨化し胞状を呈す 系粒体む膨化しその内部梁 は不規則，不明嘹となり，時に欠如しているすのるす る、湅胞基質は RNA 顆粒減少して淡明である。

付图 8：分泌顆粒排出後や>時間を経た細胞 $\times 15,000$

胞状 ER は增加乙密集して細胞は網目状を呈す. 稩 胞基質内には RNA 顆粒增加し, 系粒体は典型的形態 のものが多くなる。

付图 9：分泌休止期の細胞 $\times 9,000$

棹状，舆桿状の系粒体が豊富に見られる。細胞下部に Golgi 膜が層板状に見える. ER は不鮮明乍ら断片状に 散有している。細胞中央部の lipoid 顆粒はその内容を 、細胞形質内に放出している。

付図10：Golgi 野内の分泌顆粒 $\times 20,000$

矢印は Golgi 膜の一端が膨化し分泌物が Golgi 胞内 に眝留したるのと思われる。

上方の空胞状の顆粒は lipoid 顆粒及びlipochondris.

付図 11：Golgi 野内の ER 内に出現した分泌顆精 (矢印) $\times 9,000$

付図 12: Lipochondria $\times 9.000$

付图 13：閉鎖堤及び desmosome $\times 20,000$

左下枟内は desmosome. 電子密度の高い2 ケのプレ ートとヒダ状棈造を認める。

付図 14: 二核細胞 $\times 9,000$

付図 15: 外側核膜の膨出 $\times 20,000$

矢印の部で外側核膜は膨出し，ER と連続している.

$\mathrm{B}$ ：基底膜， $\mathrm{cm}$ : 細胞膜, $\mathrm{D}$ : Desmosome, ER： 小胞体, G：Golgi 体, GL：腺腔, id：細胞間嗍合, if : 基底陥入, icc: 細胞間分泌絓管, $1 \mathrm{~g}$ : Lipoid 顆粒, lp: Lipochondria, $\mathrm{m}$ : 系粒体, mv: microvilli, $\mathrm{N}$ : 核, $\mathrm{nl}$ : 核小体, $\mathrm{nm}$ : 核膜, $\mathrm{np}$ : 核膜細孔, $\mathrm{T}$ ：閉鎖堤， $\mathrm{sg}$ : 分泌顆粒.

䅧を䅂るにあたり御指導, 御校閱を賜た恩師西端 鼠一教授に深謝致します。文御助言, 御校閲を賜た 解剖学教室三井但夫教授に感謝致します。

本研究に対乙, 終始御懇切なる御指導, 御故撻を いたら゙いた耳舅科教室鈴木安恒助教授, 尾睤越秀博 士, 病理学教室渡辺陽之輔助教授, 坂口弘講師に深 甚の謝意を裴します

な怙多大の御援助をいたらいたた電子顕微鏡研究室 電田弘工学士，他の皆さんに厚く感謝します

本諭文の一部は日本耳奥咽喉科学会関東地方会第 367 回例会に扎いて発表した。

（原呀到着 $=$ 昭和 35.8 .26 日） 

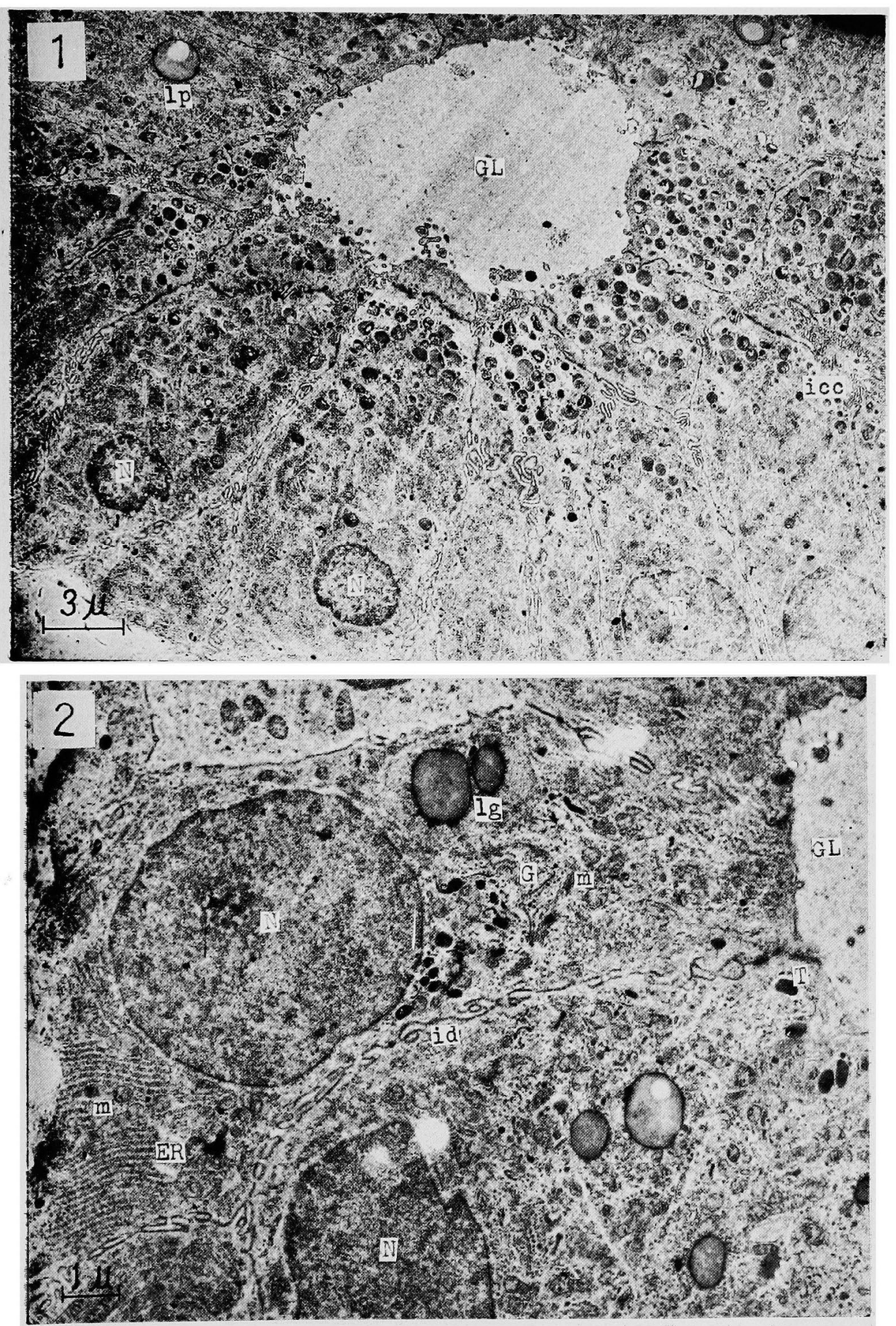


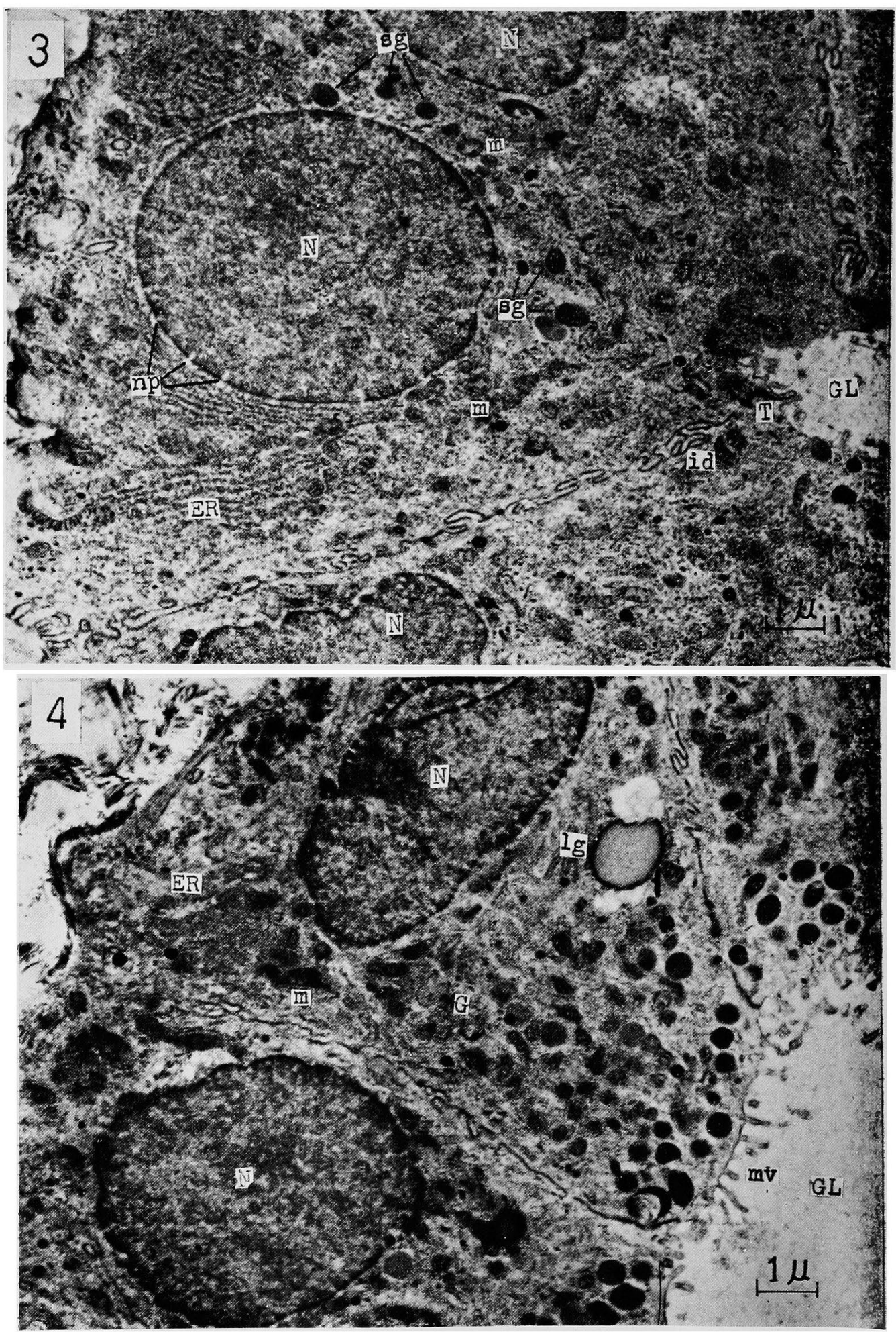


高橋論交付図 (III)

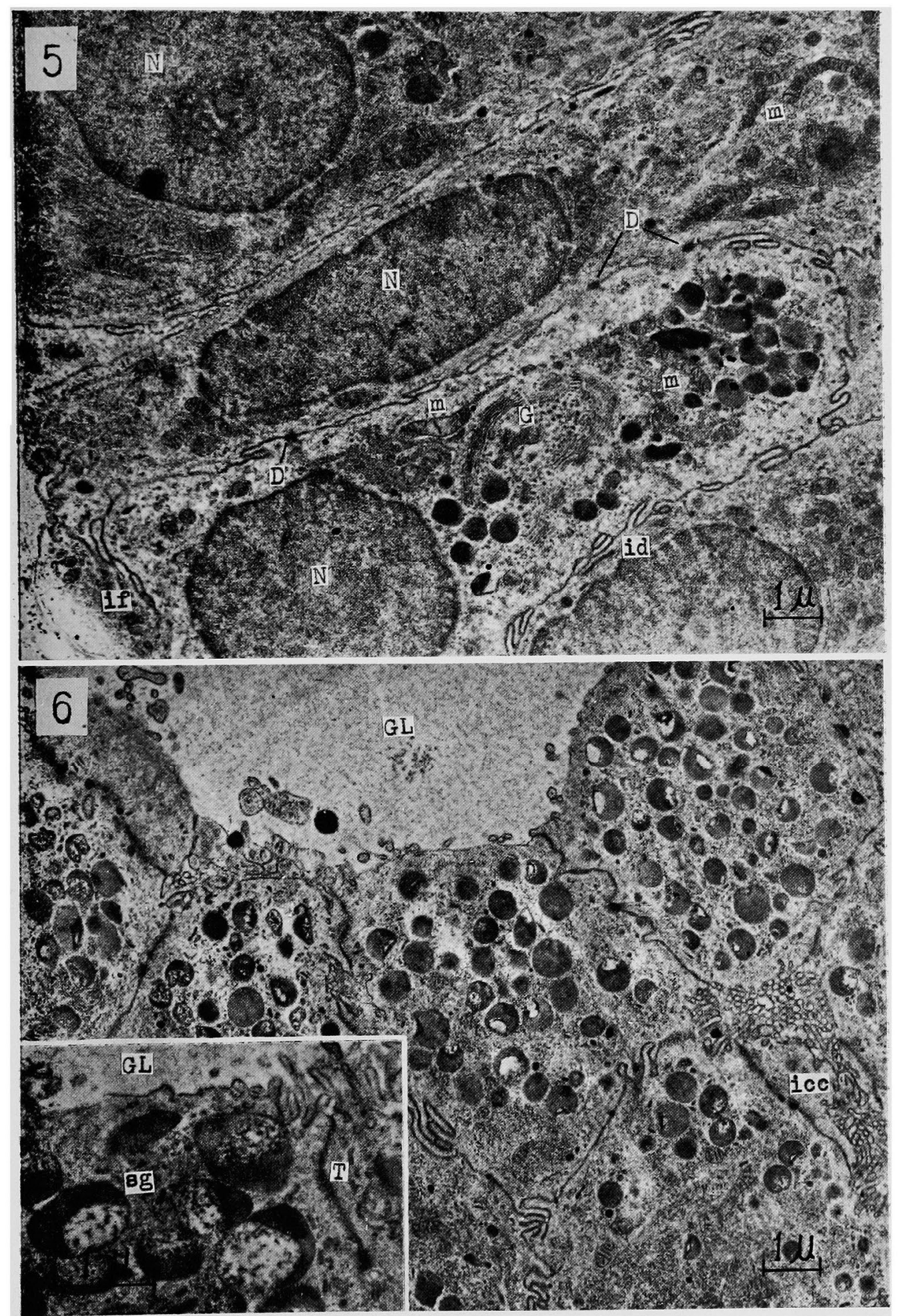


高橋論文 付図 (IV)
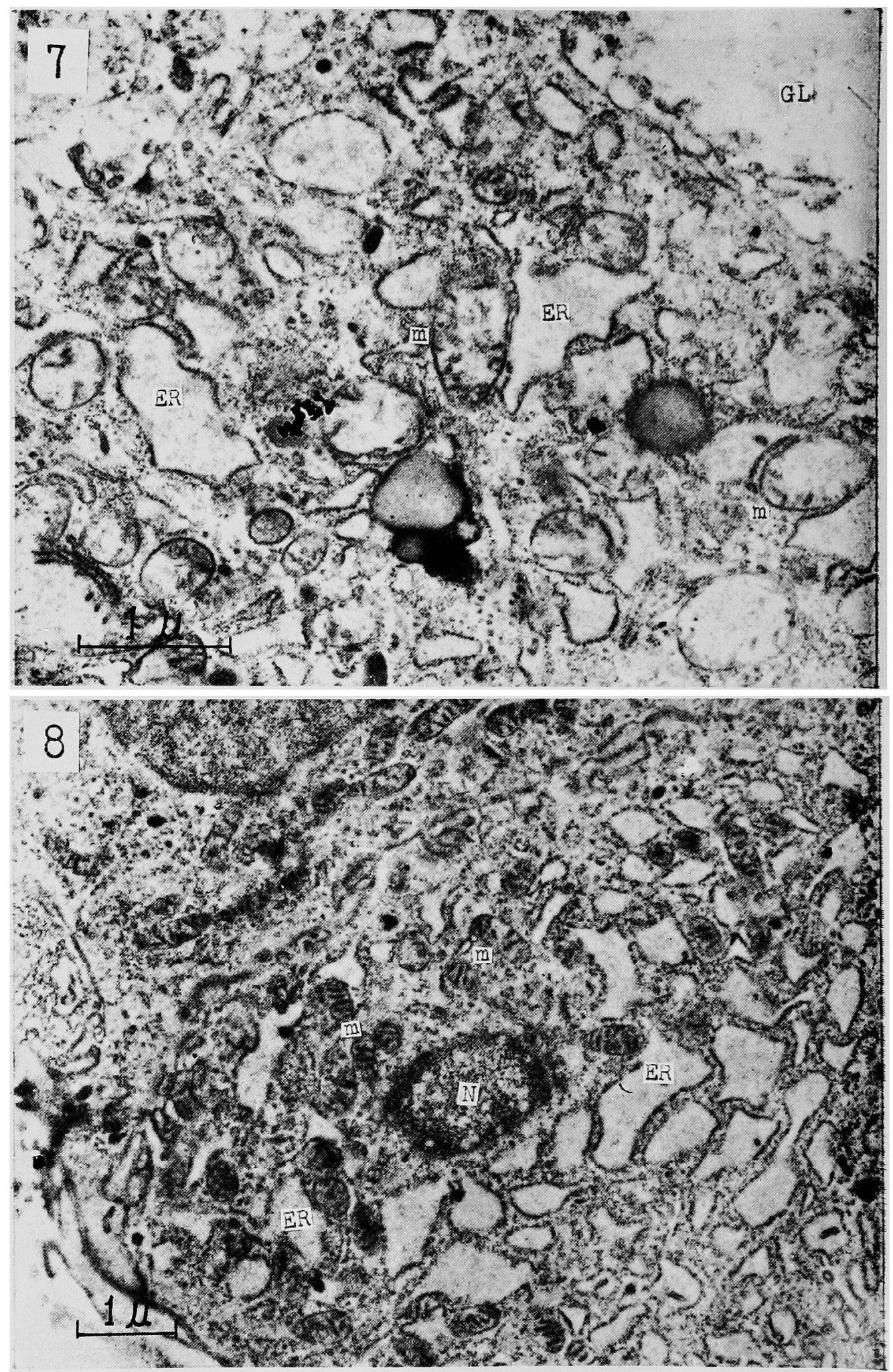

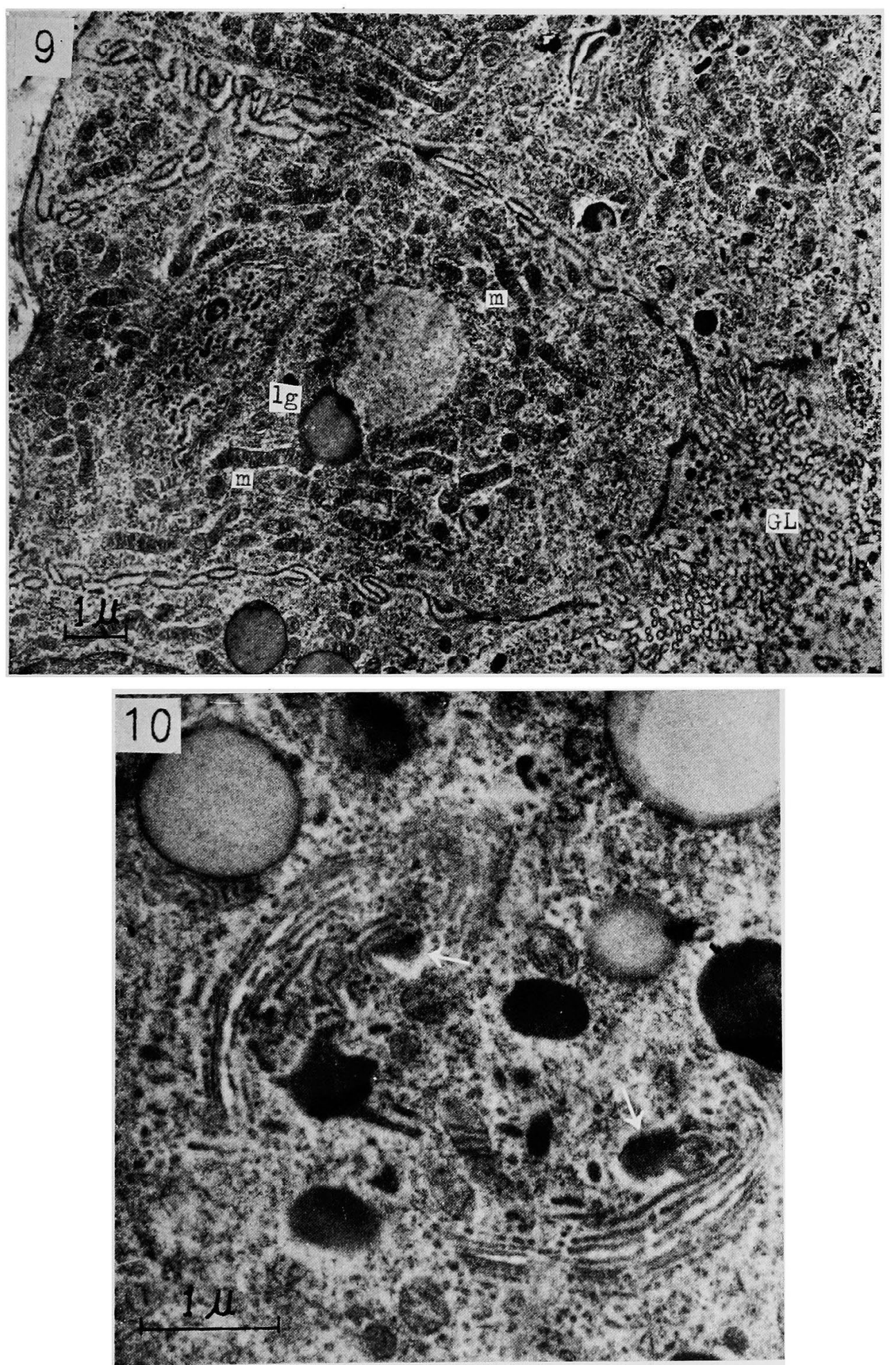


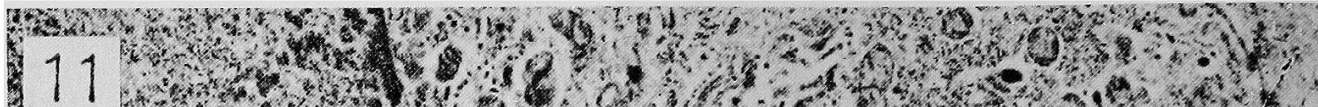

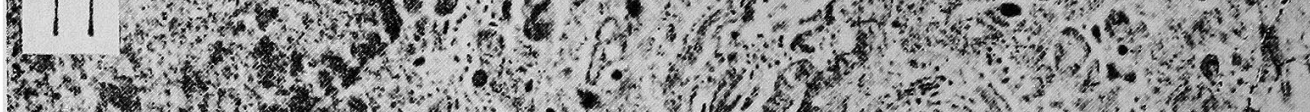

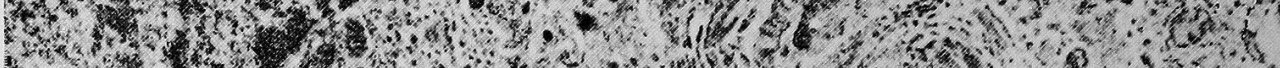
zon

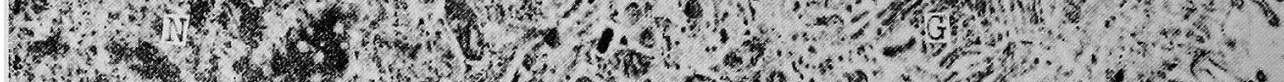

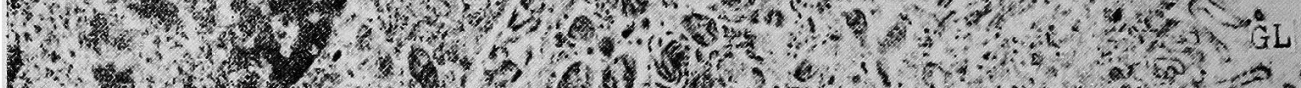

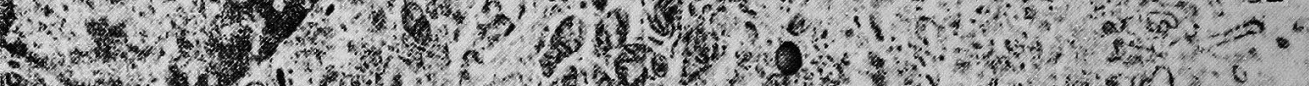

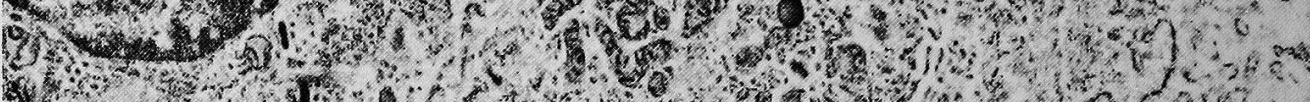
(3)

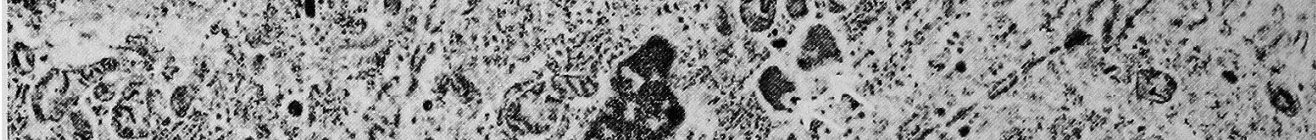
3.t. r.t.

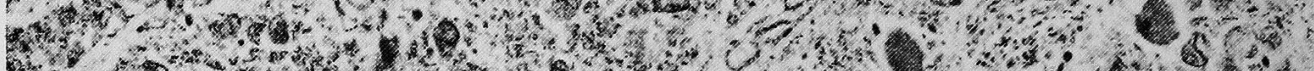

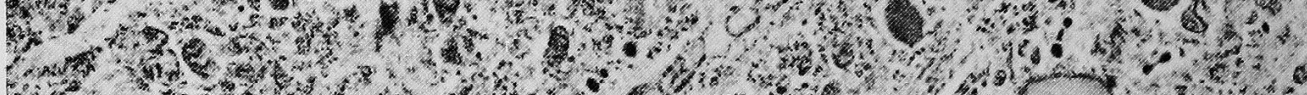

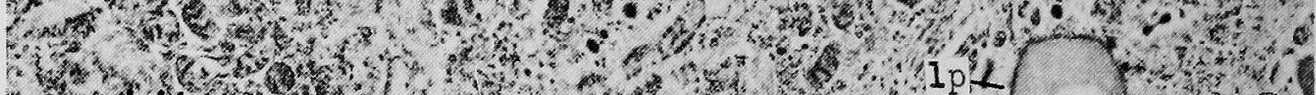

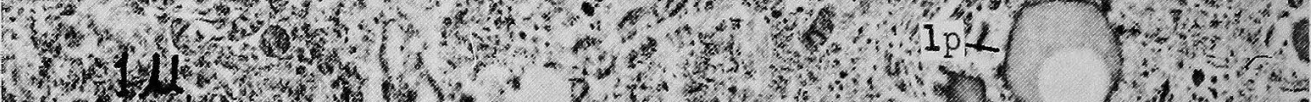

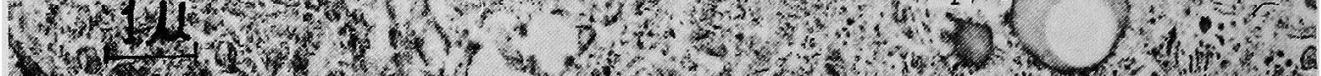

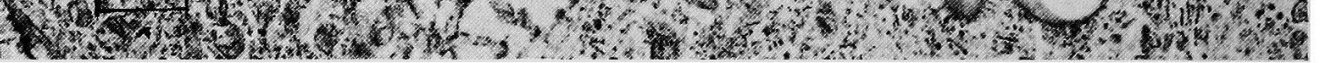

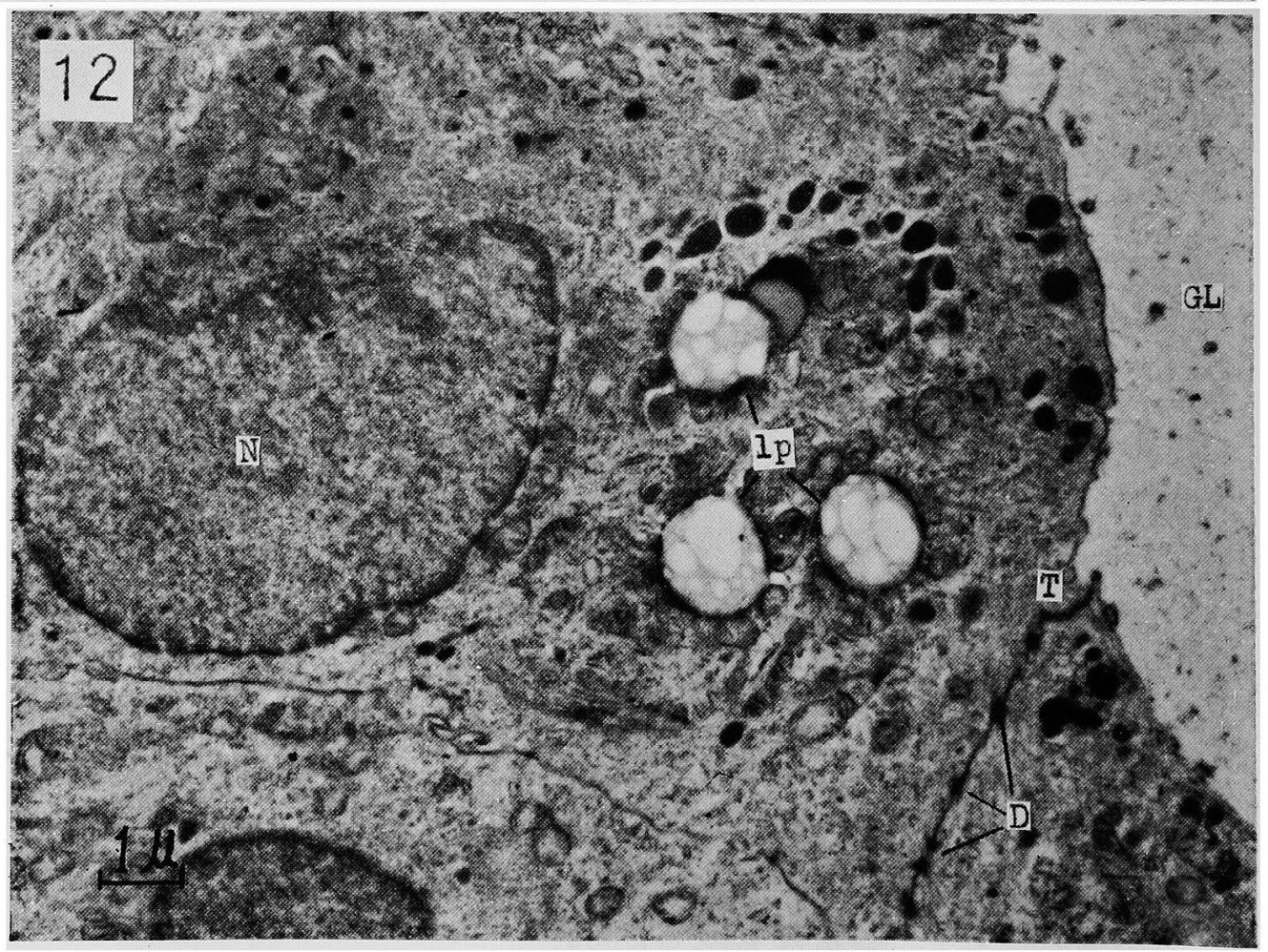


高橋論 文付圆（VII）
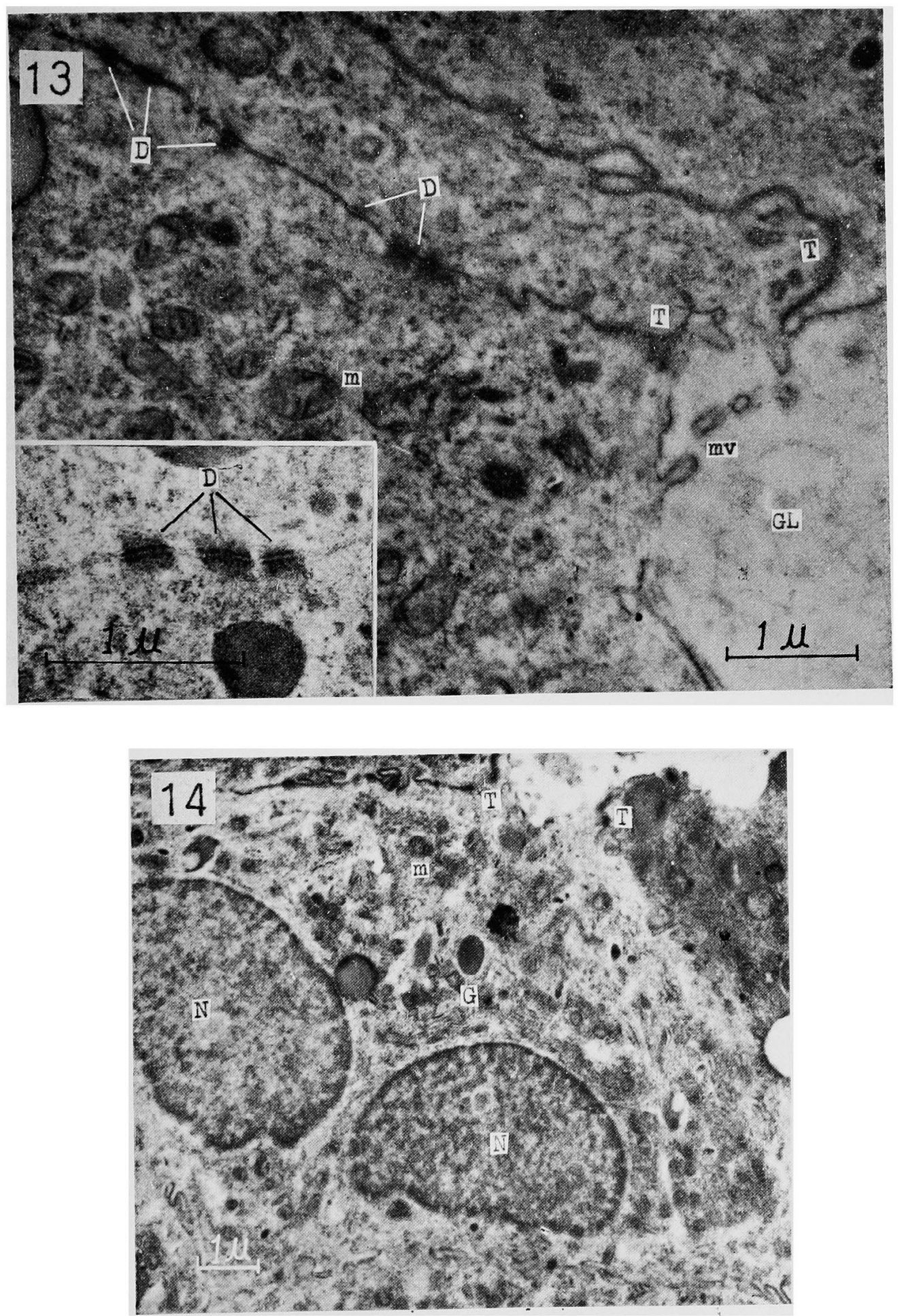
高橋論文付図 (VII)

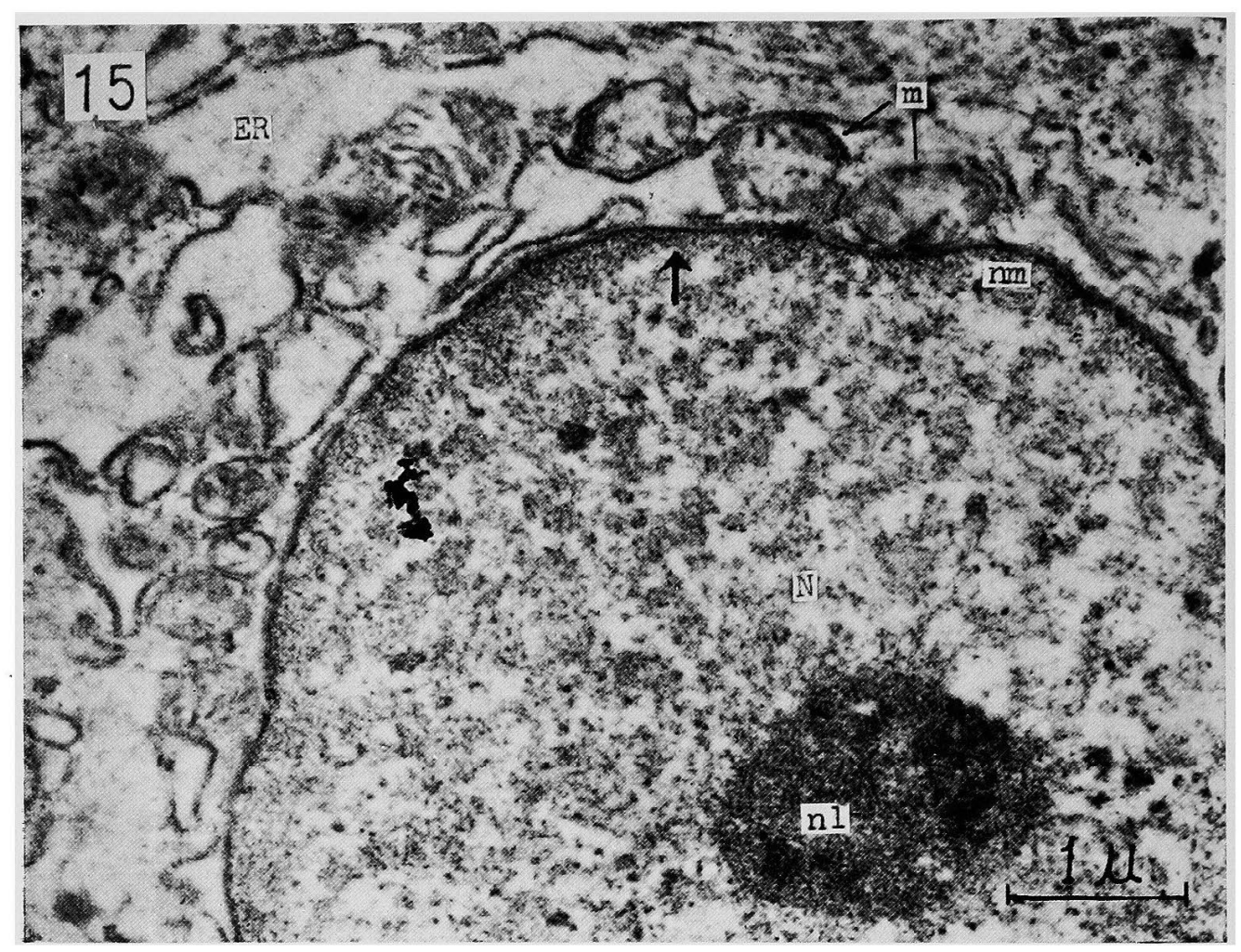

